\title{
Synthesis and Reactivity of the Ruthenium Cyclopropenyl Complex with a Tp Ligand
}

\author{
Yih-Hsing Lo, Ying-Chih Lin,* Gene-Hsiang Lee, and Yu Wang \\ Department of Chemistry, National Taiwan University, Taipe, Taiwan, 106 R.O.C.
}

Received September 4, 1998

\begin{abstract}
Treatment of $\mathrm{Tp}\left(\mathrm{PPh}_{3}\right)_{2} \mathrm{Ru}-\mathrm{C} \equiv \mathrm{C}-\mathrm{Ph}$ (1) with $\mathrm{ICH}_{2} \mathrm{CN}$ affords the cationic vinylidene complex $\left[\mathrm{Tp}\left(\mathrm{PPh}_{3}\right)_{2} \mathrm{Ru}=\mathrm{C}=\mathrm{C}(\mathrm{Ph}) \mathrm{CH}_{2} \mathrm{CN}\right] \mathrm{l}$ (2). The neutral ruthenium cyclopropenyl complex $\mathrm{Tp}\left(\mathrm{PPh}_{3}\right)_{2} \mathrm{RuC}=\mathrm{C}(\mathrm{Ph}) \mathrm{CHCN}(\mathbf{3})$ is then prepared by deprotonation of $\mathbf{2}$. Facile displacement of one phosphine ligand of 3 by $\mathrm{CH}_{3} \mathrm{CN}$ yields a diastereomeric mixture in a 4:1 ratio of the substitution product, $\mathrm{Tp}\left(\mathrm{PPh}_{3}\right)\left(\mathrm{CH}_{3} \mathrm{CN}\right) \mathrm{RuC}=\mathrm{C}(\mathrm{Ph}) \mathrm{CHCN}$ (4). The cyclopropenyl ring in 3 and 4 is susceptible to ring opening by el ectrophiles such as $\mathrm{CF}_{3} \mathrm{COOH}, \mathrm{Ph}_{3} \mathrm{CPF}_{6}$, and $\mathrm{HgCl}_{2}$. The substitution reaction of $\mathbf{3}$ with pyrazole is followed by an intramolecular nucleophilic addition of the nitrogen atom at the $\alpha$-carbon atom to afford the metallacyclic complex, $\mathrm{Tp}$ $\left(\mathrm{PPh}_{3}\right) \mathrm{Ru}\left(\mathrm{C}_{3} \mathrm{H}_{3} \mathrm{NN}\right) \mathrm{C}=\mathrm{C}(\mathrm{Ph}) \mathrm{CH}_{2} \mathrm{CN}(\mathbf{8 a})$. The reaction of $\mathbf{3}$ with $\mathrm{CO}$ in the presence of $\mathrm{MeOH}$ gives $\mathrm{Tp}\left(\mathrm{PPh}_{3}\right)(\mathrm{CO}) \mathrm{RuC}(\mathrm{OMe})=\mathrm{C}(\mathrm{Ph}) \mathrm{CH}_{2} \mathrm{CN}$ (9). The reaction of $\mathrm{CF}_{3} \mathrm{COOH}$ with 9 yields $\mathrm{Tp}\left(\mathrm{PPh}_{3}\right)(\mathrm{CO}) \mathrm{RuC}(\mathrm{O}) \mathrm{CH}(\mathrm{Ph}) \mathrm{CH}_{2} \mathrm{CN}$ (11). The structures of $\mathbf{8 a}$ and $\mathbf{1 1}$ have been determined by X-ray diffraction analysis.
\end{abstract}

\section{Introduction}

Transition-metal cyclopropenyl and vinylidene complexes have been the focus of many recent investigations. Organic cyclopropene is a highly strained cycloalkene with an estimated strain energy of more than $50 \mathrm{kcal} / \mathrm{mol} .^{1}$ This molecule has played a crucial role in the development of an important concept of aromaticity, and its chemical reactivity has been extensively explored. ${ }^{2}$ Interest in metal vinylidene complexes stems from their potential as reactive intermediates in organic and organometallic synthesis, as well as their application in catalytic processes. ${ }^{3}$ A key characteristic of vinylidene complexes appears to be the electrophilicity of the $\alpha$-carbon, which adds, often easily, amines, ${ }^{4}$ alcohols, ${ }^{5-7}$ phosphines, ${ }^{8}$ and even fluoride. ${ }^{5}$ We recently

(1) (a) Special issue on strained organic compounds: Chem. Rev. 1989, 89. (b) Liebman, J . F .; Greenberg, A. Strained Organic Molelules; Wiley: New York, 1978; p 91.

(2) Marier, G.; Periss, T.; Reisenauer, H. P.; Hess, B. A., J r.; Schand, L. J. J . Am. Chem. Soc. 1994, 116, 2014. (b) Hopf, H.; Plagens, A.; Walsh, R. J . Chem. Soc., Chem. Commum. 1994, 1467.

(3) (a) Li iebman, J . F.; Greenberg, A. Chem. Rev. 1976, 76, 311. (b) Halton, B.; Banwell, M. G. In TheChemistry of the Cyclopropnyl Group. Part 2; Patai, S., Rappoport, Z., Eds.; Wiley: Chichester, 1987; Chapter 21, p 1223.

(4) (a) Wang, Y.; Finn, M. G. J . Am. Chem. Soc. 1995, 117, 8045. (b) Bruneau, C.; Dixneuf, P. H. J . Chem. Soc., Chem. Commun. 1997, 507. (c) Bruce, M. I. Chem. Rev. 1991, 91, 197. (d) Trost, B. M. Angew. Chem. 1995, 107, 285. (e) Bianchini, C.; Peruzzini, M.; Romerosa, A.; Zanobini, F. Organometallics 1995, 14, 3152. (f) Bianchini, C.; Innocenti, P.; Peruzzini, M.; Romerosa, A.; Zanobini, F. Organometallics 1996, 15, 272. (g) Werner, H.; Wiedmann, R.; Steinert, P.; Wolf, J . Chem. Eur. J . 1997, 3, 127. (h) Trost, B. M.; Flygare, J. A. J . Am. Chem. Soc. 1992, 114, 5476. (i) Trost, B. M.; Dyker, G.; Kulawiec, R. J. Am. Chem. Soc. 1990, 112, 7809.

(5) Ting, P. C.; Lin, Y. C.; Lee, G. H.; Cheng, M. C.; Wang, Y. J . Am. Chem. Soc. 1996, 118, 6433.

(6) (a) Bruce, M. I.; Swincer, A. G.; Wallis, R. C. J . Organomet. Chem. 1979, 171, C5. (b) Bianchini, C.; Casares, J. A.; Peruzzini, M.; Romerosa, A.; Zanobini, F. J . Am. Chem. Soc. 1996, 118, 4585.

(7) (a) Barreett, A. G. M.; Carpenter, N. E. Organometallics 1987, 6, 2249. (b) Normbel, P.; Lugan, N.; Mathieu, R. J. Organomet.Chem. $1995,503, \mathrm{C} 22$. reported facile synthesis of several ruthenium cyclopropenyl complexes by deprotonation of cationic vinylidene complexes. The cationic nature of the vinylidene complex, al ong with the presence of an electron-withdrawing functionality, such as a $\mathrm{CN}$ group at $\mathrm{C} \gamma$ of the vinylidene ligand, plays a role in enhancing the acidity of the proton next to the $\mathrm{CN}$ group. Thus the base successfully effects an intramolecular cycloaddition leading to formation of a neutral cyclopropenyl complex. We in fact found the facile cyclopropenation reaction of several ruthenium vinylidene complexes containing the cyclopentadienyl ligand. Therefore we thought a similar complex containing a tris(pyrazol-1-yl)borate ligand ( $T p$, $\left.\mathrm{B}\left(\mathrm{C}_{3} \mathrm{H}_{3} \mathrm{~N}_{2}\right)_{3}\right)$ would be a suitable candidate for further investigating chemical reactivity of the ruthenium cyclopropenyl complex. In the literature, research into the coordination chemistry of the Tp ligand has mostly focused on the first-row transition metals and group VI. ${ }^{9}$ The chemistry of Tp complexes of the second- and thirdtransition series and in particular that of group VIII ${ }^{10}$ remains less developed, although there is no obvious reason this should be the case. Herein, we report preparation of two neutral tris(pyrazol-1-yl)borato ruthenium cyclopropenyl complexes: $\mathrm{Tp}\left(\mathrm{PPh}_{3}\right)_{2} \mathrm{Ru}-$ $\mathrm{C}=\mathrm{C}(\mathrm{Ph}) \mathrm{CHCN}(3)$ and $\mathrm{Tp}\left(\mathrm{PPh}_{3}\right)\left(\mathrm{CH}_{3} \mathrm{CN}\right)-\mathrm{RuC}=\mathrm{C}(\mathrm{Ph})-$ CHCN (4). Electrophilic addition to these ruthenium cyclopropenyl complexes affords new vinylidene complexes. Reaction of $\mathbf{3}$ with pyrazole gives the metallacycle product, while in the presence of $\mathrm{MeOH}$, reaction

(8) Senn, D. R.; Wong, A.; Patton, A. T.; Marsi, M.; Strouse, C. E.; Gladysz, J. A. J . Am. Chem. Soc. 1988, 110, 6096.

(9) Trofimenko, S. J . Prog. I norg. Chem. 1986, 34, 115.

(10) (a) Albers, M. O.; Robinson, D. J .; Shaver, A.; Singleton, E. Organometallics 1986, 5, 2199. (b) Hiraki, K.; Ochi, N.; Kitamura, T.; Sasada, Y.; Shinoda, S. Bull. Chem. Soc. J pn. 1982, 55, 2356. 


\section{Scheme 1}<smiles>[3H][Ge]([3H])([18F])C#CCc1ccccc1</smiles><smiles>CCCCCCCC</smiles>

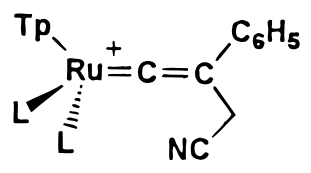

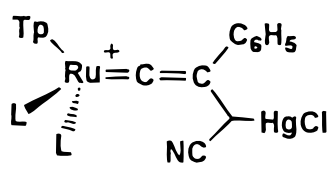<smiles>[3H]Pc1ccccc1</smiles>

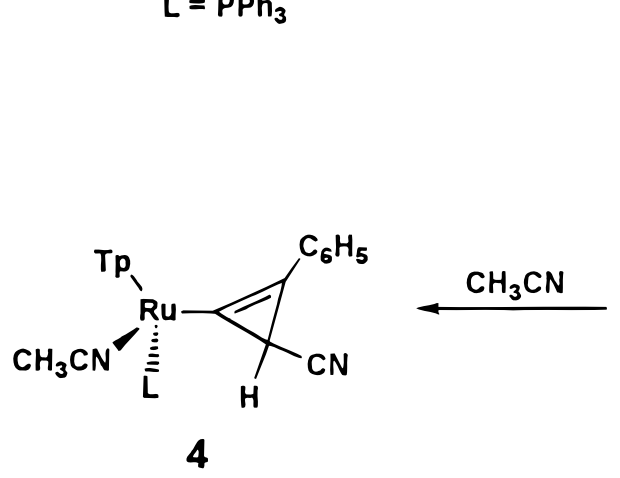<smiles>[2H][C@H](C)OC</smiles>

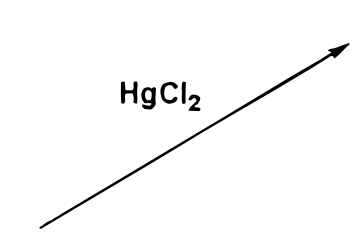

6

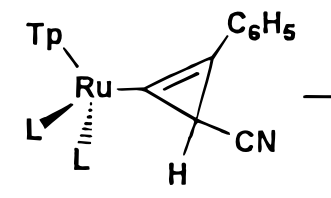

3

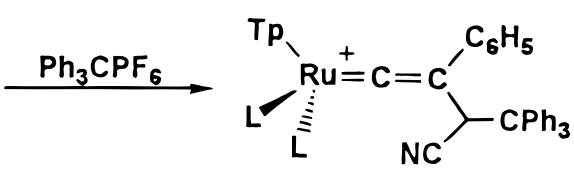

5 of $\mathbf{3}$ with $\mathrm{CO}$ gives the vinyl ether product. The mechanism of these reactions is also reported.

\section{Results and Discussion}

Tp Metal Vinylidene Complex and Its Deprotonation/Cyclopropenation. Treatment of the acetylide complex $\mathrm{Tp}\left(\mathrm{PPh}_{3}\right)_{2} \mathrm{Ru}-\mathrm{C} \equiv \mathrm{C}-\mathrm{Ph}$ (1) with $\mathrm{ICH}_{2} \mathrm{CN}$ affords the cationic vinylidene complex $\left[\mathrm{Tp}\left(\mathrm{PPh}_{3}\right)_{2^{-}}\right.$ $\left.\mathrm{Ru}=\mathrm{C}=\mathrm{C}(\mathrm{Ph}) \mathrm{CH}_{2} \mathrm{CN}\right] \mathrm{l}$ (2) with $90 \%$ yield. Complex 2 is soluble in $\mathrm{CH}_{2} \mathrm{Cl}_{2}$. Characteristic spectroscopic data of $\mathbf{2}$ consist of a strongly deshielded $\mathrm{C} \alpha$ resonance as a triplet at $\delta 375.3$ with J $\mathrm{P}-\mathrm{C}=16.5 \mathrm{~Hz}$ in the ${ }^{13} \mathrm{C} \mathrm{NMR}$ spectrum and a singlet ${ }^{31 P}$ NMR resonance at $\delta 36.5$ in $\mathrm{CDCl}_{3}$ at room temperature, which is due to fluxional behavior of the vinylidene ligand. ${ }^{11} \mathrm{~F}$ or comparison, the $\mathrm{Cp}\left(\mathrm{Cp}=\eta^{5}-\mathrm{C}_{5} \mathrm{H}_{5}\right)$ analogue displayed a triplet $\mathrm{C} \alpha$ resonance at $\delta 345.6$ with $\mathrm{J} \mathrm{P}_{-} \mathrm{C}=17.9 \mathrm{~Hz}$ in the ${ }^{13} \mathrm{C}$ NMR spectrum and a singlet 31P NMR resonance at $\delta$ 42.4 .

The ruthenium cycl opropenyl complex $\mathrm{Tp}\left(\mathrm{PPh}_{3}\right)_{2} \mathrm{Ru}-$ $\mathrm{C}=\mathrm{C}(\mathrm{Ph}) \mathrm{CHCN}$ (3) can be readily prepared by deprotonation of $\mathbf{2}$ with high yield. This reaction should be carried out at $0{ }^{\circ} \mathrm{C}$ in $\mathrm{CH}_{2} \mathrm{Cl}_{2}$ since complex 3 is thermally unstable. $\mathrm{MeONa}$ in $\mathrm{MeOH}$ is found to be a better deprotonation reagent (Scheme 1 ) even though reaction of $\mathbf{2}$ with n-Bu $\mathrm{u}_{4} \mathrm{NF}$ (1 M in THF) or DBU (1,8diazabicyclo[5.4.0]undecene) or $\mathrm{KOH}$ (dissolved in a minimum amount of $\mathrm{H}_{2} \mathrm{O}$ ) also yields $\mathbf{3}$. Complex $\mathbf{3}$ is soluble in $\mathrm{CH}_{2} \mathrm{Cl}_{2}$, THF, and ether, but is insoluble in hexane. The diastereotopic center generated by this cyclopropenation reaction causes the two phosphine ligands to be nonequivalent. Thus, in the ${ }^{31} \mathrm{P}$ NMR spectrum of 3, two doublet resonances at $\delta 48.8$ and 48.1 with J $\mathrm{P}-\mathrm{P}=29.9 \mathrm{~Hz}$ are observed. In the ${ }^{1} \mathrm{H} \mathrm{NMR}$ spectrum of 3, the singlet resonance at $\delta 1.18$ is assigned to the $\mathrm{CHCN}$ group of the three-membered ring. The resonance of the same group in the $\mathrm{Cp}$ analogue appears at $\delta$ 1.40. Facile deprotonation indicates the acidic nature of the methylene protons of $\mathbf{2}$, which may be

(11) (a) Allen, D. L.; Gison, V. C.; Green, M. L.; Skinner, T. F.; Bashikin, J .; Grebenik, P. D. J . Chem. Soc., Chem. Commum. 1985, 895. (b) Consiglio, G.; Morandini, F. Chem. Rev. 1987, 87, 761. ascribed to the combined effect of the cationic character and the presence of the el ectron-withdrawing $\mathrm{CN}$ substituent of the vinylidene complex. ${ }^{5}$ Complex $\mathbf{3}$ decomposes in $\mathrm{CDCl}_{3}$ at room temperature, producing the vinylidene compl ex $\left[\mathrm{Tp}\left(\mathrm{PPh}_{3}\right)_{2} \mathrm{Ru}=\mathrm{C}=\mathrm{C}(\mathrm{Ph}) \mathrm{CH}_{2} \mathrm{CN}\right] \mathrm{Cl}$. The proton is believed to come from trace water in the solvent.

Facile Ligand Displacement of 3. We previously reported the anal ogous Cp complex of $\mathbf{3}$, which is stable with respect to the ligand substitution reaction; that is, the phosphine ligand bonds strongly to the ruthenium center, making the coordination site unavailable for an incoming substrate. In contrast, the Tp complex $\mathbf{3}$ is susceptible to ligand substitution reaction under relatively mild conditions. For example, treatment of $\mathbf{3}$ with $\mathrm{CH}_{3} \mathrm{CN}$ at room temperature affords the air-stable ruthenium cyclopropenyl complex $\mathrm{Tp}\left(\mathrm{PPh}_{3}\right)\left(\mathrm{CH}_{3} \mathrm{CN}\right)$ -

$\mathrm{RuC}=\mathrm{C}(\mathrm{Ph}) \mathrm{CHCN}$ (4) with high yield. Complex $\mathbf{4}$ is stable in ether, $\mathrm{THF}$, and $\mathrm{CH}_{3} \mathrm{CN}$, but decomposes in $\mathrm{CDCl}_{3}$ to produce a complicated mixture. Complex 4, prepared from 3, contains two diastereomers in a 4:1 ratio, and interestingly, the major one is stable and the minor one decomposes to some unidentifiable product. The ${ }^{1} \mathrm{H}$ NMR resonances attributed to the $\mathrm{CHCN}$ of the three-membered rings of the major and the minor products appear at $\delta 1.08$ and 1.20 , respectively. In the ${ }^{13} \mathrm{C}\left\{{ }^{1} \mathrm{H}\right\} \mathrm{NMR}$ spectrum, the singlet resonance at $\delta 2.9$ and the doublet resonance at $\delta 137.9$ with ${ }^{2} \mathrm{~J}$ p-c $=11.4$ $\mathrm{Hz}$ are assigned to the $\mathrm{CHN}$ and the ruthenium-bonded $\mathrm{C} \alpha$ carbon of the major complex, respectively. The ${ }^{13} \mathrm{C}$ NMR spectrum of the minor product was not obtained because of its low stability.

Opening of the Three-Membered Ring by Electrophiles. Treatment of $\mathbf{3}$ with $\mathrm{CF}_{3} \mathrm{COOH}$ affords $\mathbf{2}$, indicating the basic character of the methyne carbon of the three-membered ring. No alkylation is observed when 3 is treated with $\mathrm{CH}_{3}, \mathrm{CH}_{3} \mathrm{CH}_{2} \mathrm{l}, \mathrm{CH}_{2}=\mathrm{CHCH}_{2}$ $\mathrm{Br}, \mathrm{CH} \equiv \mathrm{C}-\mathrm{CH}_{2} \mathrm{Br}$, and $\mathrm{ICH}_{2} \mathrm{CN}$, but treatment of $\mathbf{3}$ with trityl hexafluorophosphate at $0{ }^{\circ} \mathrm{C}$ for $20 \mathrm{~min}$ affords the cationic vinylidene complex $\left[\mathrm{Tp}\left(\mathrm{PPh}_{3}\right)_{2^{-}}\right.$ $\mathrm{Ru}=\mathrm{C}=\mathrm{C}(\mathrm{Ph}) \mathrm{CH}\left(\mathrm{CPh}_{3}\right) \mathrm{CN}_{\mathrm{P}} \mathrm{PF}_{6}$ (5) with $69 \%$ yield (Scheme 1). There are a few examples in the literature in which electrophilic addition of $\mathrm{CPh}_{3}{ }^{+}$resulted in 


\section{Scheme 2}
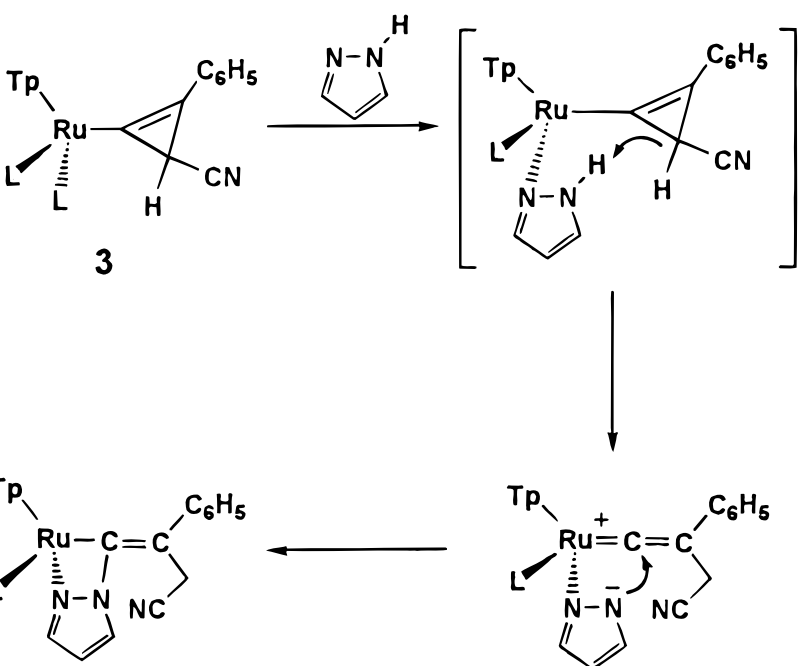

$8 a$

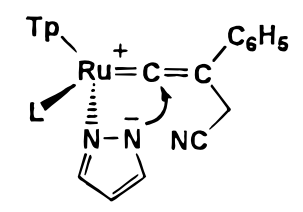

A

formation of a $\mathrm{C}-\mathrm{C}$ bond, ${ }^{15}$ even though $\mathrm{CPh}_{3}{ }^{+}$is usually considered a hydride abstractor. Treatment of 3 with $\mathrm{HgCl}_{2}$ similarly affords the addition product, [Tp$\left.\left(\mathrm{PPh}_{3}\right)_{2} \mathrm{Ru}=\mathrm{C}=\mathrm{C}(\mathrm{Ph}) \mathrm{CH}(\mathrm{HgCl}) \mathrm{CN}\right] \mathrm{Cl}$ (6), while treatment of 4 with $\mathrm{HgCl}_{2}$ also gives $\left[\mathrm{Tp}\left(\mathrm{PPh}_{3}\right)\left(\mathrm{CH}_{3} \mathrm{CN}\right)\right.$ $\mathrm{Ru}=\mathrm{C}=\mathrm{C}(\mathrm{Ph}) \mathrm{CH}(\mathrm{HgCl}) \mathrm{CN}] \mathrm{Cl}$ (7). Interestingly, only one diastereomer is observed for $\mathbf{7}$. Formation of these vinylidene complexes occurs by sel ective cleavage of the cyclopropenyl single bond near the metal center. This selectivity is similar to that reported for the asymmetrical cyclopropenes where the metal-substituted single bond was cleaved. ${ }^{16}$ Interestingly, reaction of MeONa with $\mathbf{6}$ gives the cyclopropenyl complex $\mathbf{3}$, and the reaction with $\mathbf{7}$ gives $\mathbf{4}$, but no reaction was observed in the reaction of $\mathbf{5}$ with $\mathrm{MeONa}$, which may be attributed to the steric effect of the trityl cation. ${ }^{5}$

Reaction of 3 with Pyrazole and 3,5-Dimethylpyrazole. The reaction of $\mathbf{3}$ with pyrazole in $\mathrm{CH}_{2} \mathrm{Cl}_{2}$ at room temperature did not yield the expected neutral substituted cyclopropenyl complex, but instead gave the metallacyclic complex $\mathrm{Tp}\left(\mathrm{PPh}_{3}\right) \mathrm{Ru}-\left(\mathrm{C}_{3} \mathrm{H}_{3} \mathrm{NN}\right) \mathrm{C}=\mathrm{C}(\mathrm{Ph})$ $\mathrm{CH}_{2} \mathrm{CN}$ (8a) (Scheme 2). An intermediate A was observed in the initial stage of the reaction monitored by spectroscopic methods. The ${ }^{1} \mathrm{H}$ NMR spectrum of $\mathbf{A}$ shows two doublet resonances at $\delta 4.40$ and 4.11 with $\mathrm{J} \mathrm{H}-\mathrm{H}=18.4 \mathrm{~Hz}$ assignable to gem-protons of the $\mathrm{CH}_{2}-$ $\mathrm{CN}$ group. In the ${ }^{31} \mathrm{P}$ NMR spectrum, the singlet resonance at $\delta 36.7$ is assigned to the zwitterionic vinylidene complex $\mathbf{A}$. We thus believe that the reaction first causes substitution of a phosphine ligand by a pyrazole molecule, followed by protonation to open the

(12) Christian, S.; Kurt M.; Roland S.; Kari K. Organometallics 1998, 17,827

(13) (a) Christian, S.; Kurt, M.; Roland, S.; Kari, K.J . Chem. Soc., Dalton Trans. 1997, 4209. (b) Gemel, C.; Trimmel, G.; Christian S.; Kurt M.; Roland S.; Kari K. Organometallics 1996, 15, 3998. (c) Gemel C.; Trimmel, G.; Christian, S.; Kurt M.; Roland S.; Kari, K. Inorg Chem. 1997, 36, 1076

(14) Bell, R. A.; Chisholm, M. H.; Couch, D. A.; Rankel, L. A. Inorg, Chem. 1977, 16, 677.

(15) (a) Lews, J .; Parkins, A. W. J . Chem. Soc. A 1967, 1150. (b) Schrock. R. R.; J ohnson, B. F. G.; Lewis, J .J . Chem, Soc., Dalton Trans. 1974, 951. (c) Harris, P. J .; Knox, S. A. R.; Mckinney, R. J .; Stone, F. G. A. J . Chem. Soc., Dalton Trans. 1978, 1009.

(16) Padwa, A.; Blocklock, T. J .; Getman, N.; Hatanaka, N.; Loza, R. J . Org. Chem. 1978, 43, 1481.

three-membered ring to give the intermediate $\mathbf{A}$. This is followed by nucleophilic addition of the neighboring nitrogen atom of the pyrazole group to $\mathrm{C} \alpha$ of $\mathbf{A}$ to give the metallacyclic complex 8a (Scheme 2). Complex 8a is thermally robust and stable both in solution and in solid state. The ${ }^{1} \mathrm{H}$ NMR spectrum of $\mathbf{8 a}$ displays two doublet resonances centered at $\delta 3.35$ and 3.18 with a coupling constant of $\mathrm{J} H-\mathrm{H}=17.3 \mathrm{~Hz}$ assignable to the $\mathrm{CH}_{2} \mathrm{CN}$ group. In the ${ }^{13} \mathrm{C}$ NMR spectrum, the doublet resonance at $\delta 163.3$ with ${ }^{2} \mathrm{~J} \mathrm{p}-\mathrm{C}=12.3 \mathrm{~Hz}$ is assigned to the vinyl $\mathrm{C} \alpha$. Reaction with 3,5-dimethylpyrazole gives a similar product, $\mathrm{Tp}\left(\mathrm{PPh}_{3}\right) \mathrm{Ru}\left(\mathrm{Me}_{2} \mathrm{C}_{3} \mathrm{HNN}\right)$ $\mathrm{C}=\mathrm{C}(\mathrm{Ph}) \mathrm{CH}_{2} \mathrm{CN}(\mathbf{8 b})$, in lower yield, which may be attributed to the steric effect. I $n$ the ${ }^{1} \mathrm{H}$ NMR spectrum of $\mathbf{8 b}$, two doublet resonances at $\delta 3.25$ and 3.17 with $\mathrm{J} \mathrm{H}-\mathrm{H}=17.1 \mathrm{~Hz}$ are assigned to the $\mathrm{CH}_{2} \mathrm{CN}$ group. The doublet resonance at $\delta 162.2$ with ${ }^{2} \mathrm{f}-\mathrm{C}=12.6 \mathrm{~Hz}$ in the ${ }^{13} \mathrm{C}$ NMR spectrum is assigned to the vinyl $\mathrm{C} \alpha$. A similar metallacyclic structure with a five-membered ring has also been reported recently. ${ }^{12}$

Structure of Metallacyclic Complex 8a. The molecular structure of $\mathbf{8 a}$ has been determined by X-ray diffraction analysis (Table 1 ). An ORTEP diagram is shown in Figure 1, and Table 2 lists selected bond distances and angles. The structure $\mathbf{8 a}$ contains two crystallographically independent $\mathrm{Ru}$ complexes, although there is no essential structural difference be tween them. The four-membered ring of $\mathbf{8 a}$ is puckered. The environment about the ruthenium metal center corresponds to a slightly distorted octahedron and it is obvious that the olefin in $\mathbf{8 a}$ is in an $\mathbf{E}$ configuration with the phenyl group trans to the $\mathrm{Ru}$ fragment, possibly because of steric reason. Three of the internal angles of the four-membered ring are $105.0(3)^{\circ}$, $96.7(2)^{\circ}$, and $93.0(2)^{\circ}$, while the fourth angle $\mathrm{C}(4)-$ $\mathrm{Ru}(1)-\mathrm{N}(2)$ is $65.32(14)^{\circ}$. The three $\mathrm{Ru}-\mathrm{N}(\mathrm{Tp})$ bond lengths (2.098(3), 2.142(3), and 2.156(3) $\AA$ ) are slightly longer than the average distance of $2.038 \AA$ in other chloro ruthenium $\mathrm{Tp}$ complexes.12,13 The Ru(1)-C(4) bond length of 2.087(4) $\AA$ is typical for a $\mathrm{Ru}-\mathrm{C}$ single bond. The C(4) $-C(5)$ bond length of 1.332(5) $\AA$ is typical for a $\mathrm{C}=\mathrm{C}$ double bond, indicating the coordination of the $\mathrm{sp}^{2}$ carbon of the vinyl group. However, the bond angle $\mathrm{Ru}(1)-\mathrm{C}(4)-\mathrm{N}(1)$ of $93.0(2)^{\circ}$ is much smaller than that of an idealized $\mathrm{C}\left(\mathrm{sp}^{2}\right)$ hybridization.

Reaction of 3 with $\mathrm{CO}$ in the Presence of MeOH. Reaction of $\mathbf{3}$ with $\mathrm{CO}$ in the presence of $\mathrm{MeOH}$ causes substitution of a phosphine ligand by $\mathrm{CO}$ followed by protonation of the three-membered ring by $\mathrm{MeOH}$, possibly giving a vinylidene intermediate. This is then followed by addition of the $\mathrm{MeO}^{-}$to yield the vinyl ether complex $\mathrm{Tp}\left(\mathrm{PPh}_{3}\right)(\mathrm{CO}) \mathrm{RuC}(\mathrm{OMe})=\mathrm{C}(\mathrm{Ph}) \mathrm{CH}_{2} \mathrm{CN}(\mathbf{9})$. In the ${ }^{1} \mathrm{H}$ NMR spectrum of $\mathbf{9}$, the two doublet resonances at $\delta 3.84$ and 3.02 with $\mathrm{J} \mathrm{H}-\mathrm{H}=16.8 \mathrm{~Hz}$ are assigned to the gem-protons. In the ${ }^{13} \mathrm{C}$ NMR spectrum, two doublet resonances attributed to the $\mathrm{CO}$ group and vinyl $\mathrm{C} \alpha$ appear at $\delta 204.2$ (with J $\mathrm{p}-\mathrm{C}=15.1 \mathrm{~Hz}$ ) and 188.3 (with $\mathrm{J}_{\mathrm{P}-\mathrm{C}}=14.0 \mathrm{~Hz}$ ), respectively. The $v_{\mathrm{CO}}$ stretching in the IR spectrum of 9 appears at $1957 \mathrm{~cm}^{-1}$. In the absence of $\mathrm{MeOH}$, the reaction gives an unstable complex, possibly a simple substitution product, $\mathrm{Tp}\left(\mathrm{PPh}_{3}\right)(\mathrm{CO})$ $\mathrm{RuC}=\mathrm{C}(\mathrm{Ph}) \mathrm{CHCN}(\mathbf{B})$. We believe that the reaction may proceed through substitution as the first step, followed by opening of the cyclopropenyl ring by $\mathrm{MeOH}$ to give a 
Table 1. Crystal and Intensity Collection Data for $\mathrm{Tp}\left(\mathrm{PPh}_{3}\right) \mathrm{Ru}\left(\mathrm{C}_{3} \mathrm{H}_{3} \mathrm{NN}\right) \mathrm{C}=\mathrm{C}(\mathrm{Ph}) \mathrm{CH}_{2} \mathrm{CN}(8 \mathrm{a})$ and $\mathrm{Tp}\left(\mathrm{PPh}_{3}\right)(\mathrm{CO}) \mathrm{RuC}(\mathrm{O}) \mathrm{CHPhCH} \mathrm{CHN}_{2}$ (11)

\begin{tabular}{|c|c|c|}
\hline $\begin{array}{l}\text { no. of reflns collected } \\
\text { no. of ind reflns } \\
\text { max. and min. transmission } \\
\text { refinement method } \\
\text { no. of data/restraints/params } \\
\text { GOF } \\
\text { final R indices }[I>2 \sigma(I)] \\
\mathrm{R} \text { indices (all data) } \\
\Delta \rho \text { (in final map), e/A }\end{array}$ & $\begin{array}{l}\mathrm{C}_{40} \mathrm{H}_{34} \mathrm{BN}{ }_{9} \mathrm{PRu}(8 \mathrm{a}) \\
783.61 \\
\mathrm{P} \overline{1} \\
11.6820(2) \\
17.1746(2) \\
19.7647(3) \\
73.720(1) \\
81.073(1) \\
89.822(1) \\
3756.94(10) \\
4 \\
0.25 \times 0.25 \times 0.20 \\
0.71073 \\
1.09-25.02 \\
-8 \leq \mathrm{h} \leq 13 \\
-20 \leq \mathrm{k} \leq 19 \\
-22 \leq \mathrm{I} \leq 23 \\
21248 \\
13076 \\
0.8944 \text { and } 0.7076 \\
13076 / 0 / 938 \\
1.00 \\
\mathrm{R} 1=0.0426, W_{2}=0.0917 \\
\mathrm{R} 1=0.0737, \mathrm{WR}_{2}=0.1094 \\
-0.468,+0.593\end{array}$ & $\begin{array}{l}\mathrm{C}_{38} \mathrm{H}_{32} \mathrm{BN}_{7} \mathrm{O}_{2} \mathrm{PRu}(11) \\
761.56 \\
\mathrm{P} \overline{1} \\
10.9969(1) \\
12.3088(1) \\
13.3739(2) \\
84.618(1) \\
88.934(1) \\
75.641(1) \\
1745.97(3) \\
2 \\
0.40 \times 0.25 \times 0.10 \\
0.71073 \\
1.53-26.37 \\
-13 \leq \mathrm{h} \leq 11 \\
-15 \leq \mathrm{K} \leq 15 \\
-16 \leq \mathrm{I} \leq 16 \\
14140 \\
7080 \\
0.8273 \text { and } 0.7059 \\
\text { es } \mathrm{F} \mathrm{F}^{2} \\
7080 / 0 / 451 \\
1.023 \\
\mathrm{R} 1=0.0420, \mathrm{WR}_{2}=0.0956 \\
\mathrm{R} 1=0.0590, \mathrm{WR}_{2}=0.1043 \\
-0.426,+0.917\end{array}$ \\
\hline
\end{tabular}

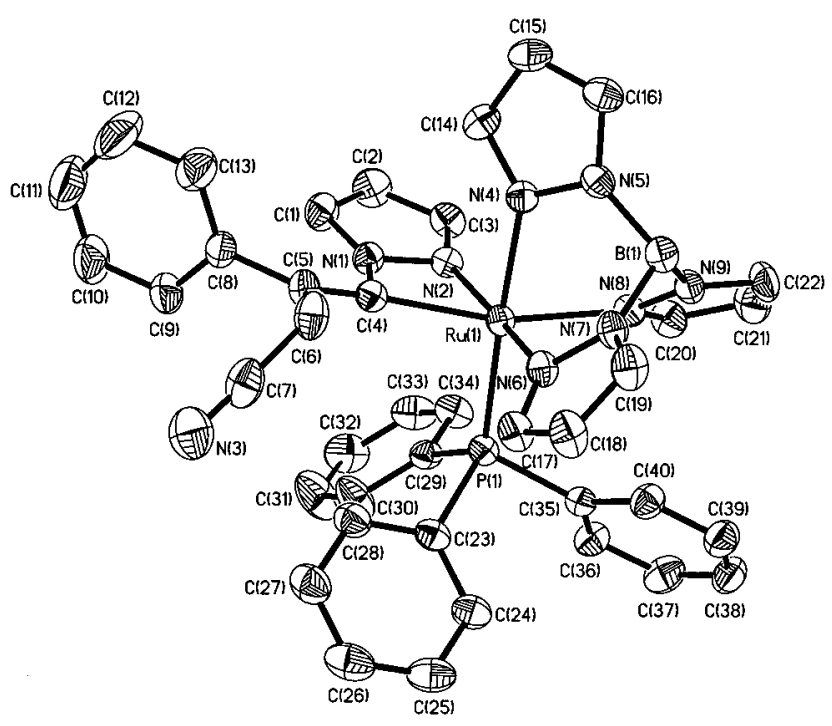

Figure 1. ORTEP drawing of 8a with thermal ellipsoids shown at the $50 \%$ probability level.

vinylidene ligand. Nucleophilic attack of $\mathrm{MeO}^{-}$at the $\alpha$-carbon atom of the vinylidene ligand would then give the final product (Scheme 3). In our previous paper, we reported that $\mathrm{MeOH}$ is able to open certain threemembered rings. ${ }^{5}$ The reaction of $\mathbf{9}$ with $\mathrm{CF}_{3} \mathrm{COOH}$ in $\mathrm{CH}_{2} \mathrm{Cl}_{2}$ at room temperature ultimately leads to the formation of acylruthenium complex $\mathrm{Tp}\left(\mathrm{PPh}_{3}\right)(\mathrm{CO}) \mathrm{Ru}-$ $\mathrm{C}(\mathrm{O}) \mathrm{CH}(\mathrm{Ph}) \mathrm{CH}_{2} \mathrm{CN}$ (11). When the reaction is followed by ${ }^{1} \mathrm{H}$ NMR spectroscopy, initial formation of the cationic al koxycarbene complex $\left[\mathrm{Tp}\left(\mathrm{PPh}_{3}\right)(\mathrm{CO}) \mathrm{Ru}=\mathrm{C}(\mathrm{OM})\right.$ $\left.\mathrm{CH}(\mathrm{Ph}) \mathrm{CH}_{2} \mathrm{CN}\right]\left[\mathrm{CF}_{3} \mathrm{COO}\right]$ (10) was apparent, then followed by a slow reaction to give complex $\mathbf{1 1}$. Chisholm and co-workers ${ }^{14}$ reported a similar reaction of $\mathrm{Pt}$ complexes.

When 9 was treated with $\mathrm{HOAC}$ in $\mathrm{CH}_{2} \mathrm{Cl}_{2}$, no reaction was observed. The $v_{\mathrm{CO}}$ stretching bands of $\mathbf{1 0}$ and $\mathbf{1 1}$ appear at 1998 and $1983 \mathrm{~cm}^{-1}$, respectively, in their IR spectra. The doublet resonance at $\delta 213.6$ with ${ }^{2} \mathrm{f}-\mathrm{C}=13.4 \mathrm{~Hz}$ in the ${ }^{13} \mathrm{C}$ NMR spectrum of $\mathbf{1 0}$ is
Table 2. Selected Bond Distances $(\AA \AA)$ and Angles (deg) of $\mathrm{Tp}\left(\mathrm{PPh}_{3}\right) \mathrm{Ru}\left(\mathrm{C}_{3} \mathrm{H}_{3} \mathrm{NN}\right) \mathrm{C}=\mathrm{C}(\mathrm{Ph}) \mathrm{CH}_{2} \mathrm{CN}$ (8a)

\begin{tabular}{lcll}
\hline $\mathrm{Ru}(1)-\mathrm{N}(2)$ & $2.071(3)$ & $\mathrm{Ru}(1)-\mathrm{C}(4)$ & $2.087(4)$ \\
$\mathrm{Ru}(1)-\mathrm{N}(6)$ & $2.098(3)$ & $\mathrm{Ru}(1)-\mathrm{N}(4)$ & $2.142(3)$ \\
$\mathrm{Ru}(1)-\mathrm{N}(8)$ & $2.156(3)$ & $\mathrm{Ru}(1)-\mathrm{P}(1)$ & $2.2801(11)$ \\
$\mathrm{N}(1)-\mathrm{C}(1)$ & $1.361(5)$ & $\mathrm{N}(2)-\mathrm{C}(3)$ & $1.309(5)$ \\
$\mathrm{N}(1)-\mathrm{C}(4)$ & $1.461(5)$ & $\mathrm{C}(1)-\mathrm{C}(2)$ & $1.372(6)$ \\
$\mathrm{N}(3)-\mathrm{C}(7)$ & $1.125(6)$ & $\mathrm{C}(2)-\mathrm{C}(3)$ & $1.394(6)$ \\
$\mathrm{C}(4)-\mathrm{C}(5)$ & $1.332(5)$ & $\mathrm{C}(5)-\mathrm{C}(6)$ & $1.511(6)$ \\
$\mathrm{C}(6)-\mathrm{C}(7)$ & $1.486(7)$ & $\mathrm{C}(5)-\mathrm{C}(8)$ & $1.493(6)$ \\
$\mathrm{N}(2)-\mathrm{Ru}(1)-\mathrm{C}(4)$ & $65.32(14)$ & $\mathrm{N}(2)-\mathrm{Ru}(1)-\mathrm{C}(6)$ & $169.28(13)$ \\
$\mathrm{C}(4)-\mathrm{Ru}(1)-\mathrm{N}(6)$ & $105.91(14)$ & $\mathrm{N}(2)-\mathrm{Ru}(1)-\mathrm{N}(4)$ & $87.65(12)$ \\
$\mathrm{C}(4)-\mathrm{Ru}(1)-\mathrm{N}(4)$ & $86.88(14)$ & $\mathrm{N}(6)-\mathrm{Ru}(1)-\mathrm{N}(4)$ & $65.65(12)$ \\
$\mathrm{N}(2)-\mathrm{Ru}(1)-\mathrm{N}(8)$ & $99.62(13)$ & $\mathrm{C}(4)-\mathrm{Ru}(1)-\mathrm{N}(8)$ & $162.52(14)$ \\
$\mathrm{N}(6)-\mathrm{Ru}(1)-\mathrm{N}(8)$ & $87.94(12)$ & $\mathrm{N}(4)-\mathrm{Ru}(1)-\mathrm{N}(8)$ & $83.52(12)$ \\
$\mathrm{N}(2)-\mathrm{Ru}(1)-\mathrm{P}(1)$ & $94.09(9)$ & $\mathrm{C}(4)-\mathrm{Ru}(1)-\mathrm{P}(1)$ & $95.33(11)$ \\
$\mathrm{N}(6)-\mathrm{Ru}(1)-\mathrm{P}(1)$ & $92.87(9)$ & $\mathrm{N}(4)-\mathrm{Ru}(1)-\mathrm{P}(1)$ & $177.61(9)$ \\
$\mathrm{N}(8)-\mathrm{Ru}(1)-\mathrm{P}(1)$ & $94.56(9)$ & $\mathrm{N}(2)-\mathrm{N}(1)-\mathrm{C}(4)$ & $105.0(3)$ \\
$\mathrm{N}(1)-\mathrm{N}(2)-\mathrm{Ru}(1)$ & $96.7(2)$ & $\mathrm{N}(1)-\mathrm{C}(4)-\mathrm{Ru}(1)$ & $93.0(2)$ \\
$\mathrm{C}(4)-\mathrm{C}(5)-\mathrm{C}(8)$ & $126.3(4)$ & $\mathrm{C}(8)-\mathrm{C}(5)-\mathrm{C}(6)$ & $114.1(4)$ \\
$\mathrm{N}(3)-\mathrm{C}(7)-\mathrm{C}(6)$ & $176.7(6)$ & $\mathrm{C}(7)-\mathrm{C}(6)-\mathrm{C}(5)$ & $113.5(4)$
\end{tabular}

assigned to the acyl carbon atom. The two characteristic ${ }^{13} \mathrm{C}$ doublet resonances at $\delta 319.9$ (with $\mathrm{p}-\mathrm{C}=10.0 \mathrm{~Hz}$ ) and $201.5(\mathrm{~J}-\mathrm{C}=12.8 \mathrm{~Hz})$ are assigned to the carbene $\mathrm{C} \alpha$ and the terminal $\mathrm{CO}$ group, respectively. In the ${ }^{1 \mathrm{H}}$ NMR spectrum of $\mathbf{1 1}$, the two multiplet resonances at $\delta 3.75$ and 3.21 are assigned to the $\mathrm{CH}_{2} \mathrm{CN}$ group. Orange-red crystals of $\mathbf{1 1}$ were obtained by slow diffusion of hexane into the ether solution of $\mathbf{1 1}$ at $0{ }^{\circ} \mathrm{C}$ for 3 days. The structure of $\mathbf{1 1}$ is determined by X-ray diffraction analysis. An ORTEP diagram is shown in Figure 2, and Table 3 lists selected bond distances and angles. The geometry around the metal center of $\mathbf{1 1}$ is approximately octahedral. The $\mathrm{C}(2)-\mathrm{O}(2)$ bond length of 1.214(4) $\AA$ and the Ru-C(2)-C(3) bond angle of $124.7(2)^{\circ}$ are characteristic for an acyl group. The $\mathrm{Ru}-\mathrm{C}(2)$ bond length of 2.042(4) $\AA$ is typical of a Ru-C single bond. The C(1)-O(1) bond distance of 1.140(4) $\AA$ indicates terminal $\mathrm{CO}$ coordinate at the ruthenium center.

Concluding Remarks. The cyclopropenyl ruthenium complex $\mathbf{3}$ containing a Tp ligand was prepared from deprotonation of the vinylidene precursor. Unlike 
Scheme 3

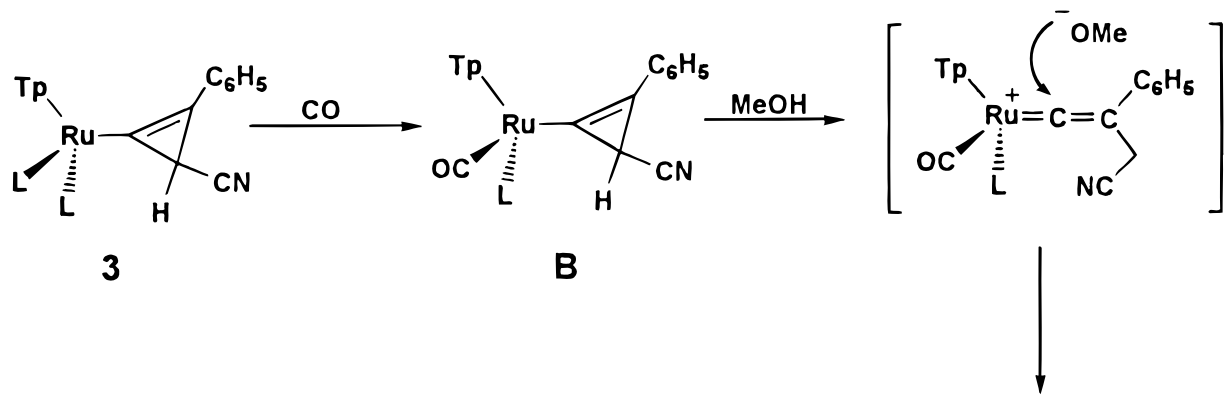

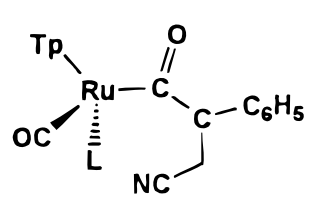

11

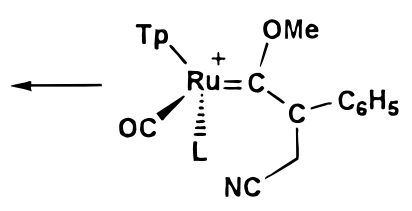

10<smiles>O=C(O)CC1(C(F)(F)F)CC1</smiles><smiles>COC(=C(CC#N)c1ccccc1)[C@](C)([O-])Cl</smiles>

9

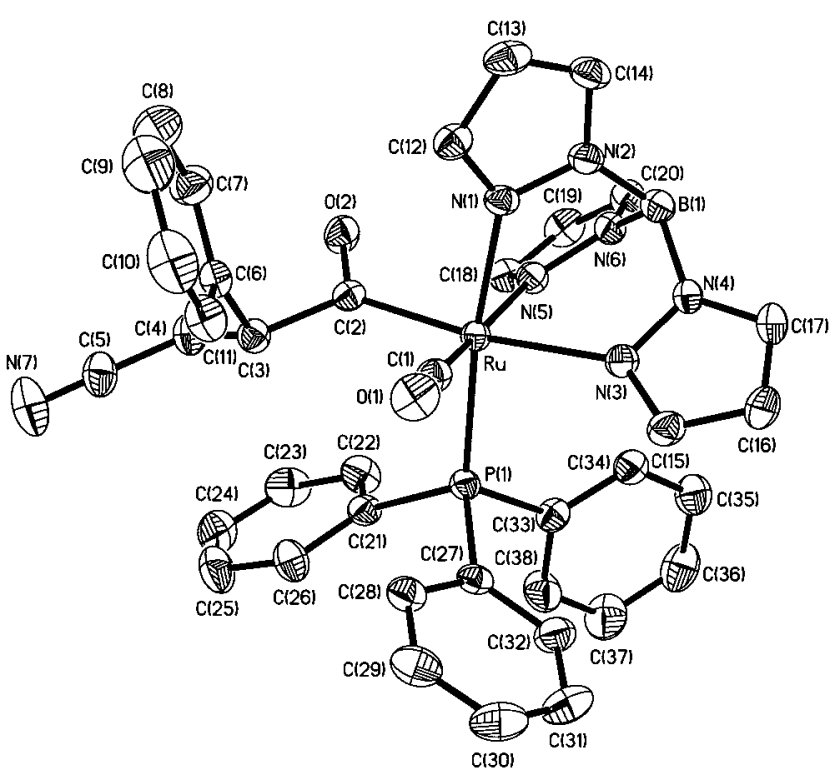

Figure 2. ORTEP drawing of $\mathbf{1 1}$ with thermal ellipsoids shown at the $50 \%$ probability level.

Table 3. Selected Bond Distances $(\AA)$ and Angles (deg) of $\mathrm{Tp}\left(\mathrm{PPh}_{3}\right)(\mathrm{CO}) \mathrm{RuC}(\mathrm{O}) \mathrm{CH}(\mathrm{Ph}) \mathrm{CH}_{2} \mathrm{CN}$ (11)

\begin{tabular}{lclc}
\hline $\mathrm{Ru}-\mathrm{C}(1)$ & $1.846(4)$ & $\mathrm{Ru}-\mathrm{C}(2)$ & $2.042(3)$ \\
$\mathrm{Ru}-\mathrm{N}(1)$ & $2.125(3)$ & $\mathrm{Ru}-\mathrm{N}(5)$ & $2.162(3)$ \\
$\mathrm{Ru}-\mathrm{N}(3)$ & $2.208(3)$ & $\mathrm{Ru}(1)-\mathrm{P}(1)$ & $2.3599(9)$ \\
$\mathrm{C}(1)-\mathrm{O}(1)$ & $1.140(5)$ & $\mathrm{N}(7)-\mathrm{C}(5)$ & $1.130(4)$ \\
$\mathrm{C}(2)-\mathrm{C}(3)$ & $1.571(5)$ & $\mathrm{C}(3)-\mathrm{C}(4)$ & $1.543(5)$ \\
$\mathrm{C}(4)-\mathrm{C}(5)$ & $1.456(5)$ & $\mathrm{C}(2)-\mathrm{O}(2)$ & $1.214(4)$ \\
$\mathrm{C}(1)-\mathrm{Ru}-\mathrm{C}(2)$ & $94.42(13)$ & $\mathrm{C}(1)-\mathrm{Ru}-\mathrm{N}(1)$ & $89.36(13)$ \\
$\mathrm{C}(2)-\mathrm{Ru}-\mathrm{N}(6)$ & $90.38(11)$ & $\mathrm{C}(1)-\mathrm{Ru}-\mathrm{N}(5)$ & $171.93(13)$ \\
$\mathrm{C}(2)-\mathrm{Ru}-\mathrm{N}(5)$ & $88.83(12)$ & $\mathrm{N}(1)-\mathrm{Ru}-\mathrm{N}(5)$ & $83.22(11)$ \\
$\mathrm{C}(1)-\mathrm{Ru}-\mathrm{N}(3)$ & $89.20(12)$ & $\mathrm{C}(2)-\mathrm{Ru}-\mathrm{N}(3)$ & $172.25(12)$ \\
$\mathrm{N}(1)-\mathrm{Ru}-\mathrm{N}(3)$ & $82.80(10)$ & $\mathrm{N}(5)-\mathrm{Ru}-\mathrm{N}(3)$ & $86.72(10)$ \\
$\mathrm{C}(1)-\mathrm{Ru}-\mathrm{P}(1)$ & $92.69(11)$ & $\mathrm{C}(2)-\mathrm{Ru}-\mathrm{P}(1)$ & $95.22(9)$ \\
$\mathrm{N}(1)-\mathrm{Ru}-\mathrm{P}(1)$ & $173.87(8)$ & $\mathrm{N}(5)-\mathrm{Ru}-\mathrm{P}(1)$ & $94.37(8)$ \\
$\mathrm{N}(3)-\mathrm{Ru}-\mathrm{P}(1)$ & $91.45(7)$ & $\mathrm{O}(2)-\mathrm{C}(2)-\mathrm{C}(3)$ & $114.1(3)$ \\
$\mathrm{O}(1)-\mathrm{C}(1)-\mathrm{Ru}$ & $172.9(3)$ & $\mathrm{O}(2)-\mathrm{C}(2)-\mathrm{Ru}$ & $121.1(2)$ \\
$\mathrm{C}(3)-\mathrm{C}(2)-\mathrm{Ru}$ & $121.1(2)$ & $\mathrm{C}(4)-\mathrm{C}(3)-\mathrm{C}(2)$ & $107.8(3)$ \\
$\mathrm{N}(7)-\mathrm{C}(5)-\mathrm{C}(4)$ & $176.6(5)$ & & \\
& & &
\end{tabular}

its Cp analogue, the Tp cyclopropenyl complex $\mathbf{3}$ undergoes facile phosphine substitution reaction with several donor molecules. This property was employed to prepare novel complexes of Ru. For example, $\mathrm{CH}_{3}-$
$\mathrm{CN}$ readily displaces one of the phosphine ligands of $\mathbf{3}$ to give a mixture of diastereomers in a 4:1 ratio. Reaction of $\mathbf{3}$ with pyrazole gives the metallacyclic product $\mathbf{8 a}$ resulting from a displacement reaction followed by nucleophilic addition of the nitrogen atom to the $\mathrm{C} \alpha$. Reaction of $\mathbf{3}$ with $\mathrm{CO}$ in the presence of $\mathrm{MeOH}$ follows a similar pathway to yield the vinyl ether complex 9.

\section{Experimental Section}

General Procedure. All manipulations were performed under nitrogen using vacuum-line, drybox, and standard Schlenk techniques. $\mathrm{CH}_{3} \mathrm{CN}$ and $\mathrm{CH}_{2} \mathrm{Cl}_{2}$ were distilled from $\mathrm{CaH}_{2}$ and diethyl ether, while THF was from $\mathrm{Na}$ /ketyl. All other solvents and reagents were of reagent grade and used without further purification. NMR spectra were recorded on Bruker AC-200 and AM-300WB FT-NMR spectrometers at room temper ature (unless stated otherwise) and are reported in $\delta$ units with residual protons in the solvent as an internal standard $\left(\mathrm{CDCl}_{3}, \delta 7.24 ; \mathrm{CD}_{3} \mathrm{CN}, \delta 1.93 ; \mathrm{C}_{2} \mathrm{D}_{6} \mathrm{CO}, \delta 2.04\right)$. $\mathrm{FAB}$ mass spectra were recorded on a J EOL SX-102A spectrometer. $\mathrm{Tp}\left(\mathrm{PPh}_{3}\right)_{2} \mathrm{RuCl}^{17}$ was prepared by following the method re ported in the literature. Elemental analyses and X-ray diffraction studies were carried out at the Regional Center of Analytical Instruments at National Taiwan University.

Preparation of $\mathbf{T} \mathbf{p}\left(\mathbf{P P h}_{\mathbf{3}}\right)_{\mathbf{2}} \mathbf{R} \mathbf{u}-\mathbf{C} \equiv \mathbf{C}-\mathbf{P h}$ (1). To a $50 \mathrm{~mL}$ $\mathrm{MeOH}$ solution of $\mathrm{Tp}\left(\mathrm{PPh}_{3}\right)_{2} \mathrm{RuCl}(3.93 \mathrm{~g}, 4.50 \mathrm{mmol})$ were added excess phenylacetylene $(4.17 \mathrm{~mL}, 10$ equiv) and excess $E t_{3} \mathrm{~N}$, and the solution was heated to reflux for $90 \mathrm{~min}$. The yell ow precipitates formed and, after cooling, were filtered off and washed with $\mathrm{MeOH}$ and hexane. This yellow solid product was dried under vacuum to give compound 1 (3.34 g, 79\% yield). Spectroscopic data for ${ }^{1}$ : ${ }^{1} \mathrm{H} N M R\left(\mathrm{CDCl}_{3}\right): \delta 7.58(\mathrm{~d}$,

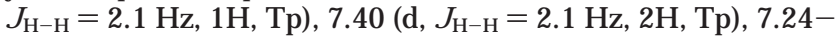
$6.91\left(\mathrm{~m}, \mathrm{PPh}_{3}, \mathrm{Tp}\right), 5.54\left(\mathrm{t}, \mathrm{J}_{\mathrm{H}-\mathrm{H}}=2.1 \mathrm{~Hz}, 2 \mathrm{H}, \mathrm{Tp}\right), 5.31(\mathrm{t}$, $\mathrm{J} \mathrm{H}-\mathrm{H}=2.1 \mathrm{~Hz}, 1 \mathrm{H}, \mathrm{Tp}), 5.20\left(\mathrm{~d}, \mathrm{~J}_{\mathrm{H}-\mathrm{H}}=2.1 \mathrm{~Hz}, 1 \mathrm{H}, \mathrm{Tp}\right) .{ }^{13} \mathrm{C}$ NMR (acetone): $\delta 135.8(\mathrm{t}, \mathrm{J} \mathrm{p}-\mathrm{c}=12.3 \mathrm{~Hz}, \mathrm{C} \alpha$ ), 145.7-122.7 $\left(\mathrm{Ph}, \mathrm{Tp}, \mathrm{PPh}_{3}, \mathrm{C}_{\beta}\right)$. ${ }^{31 \mathrm{P} N M R}\left(\mathrm{CDCl}_{3}\right): \delta$ 48.6. MS (FAB) m/z: 940.1 $\left(\mathrm{M}^{+}\right), 678.1\left(\mathrm{M}^{+}-\mathrm{PPh}_{3}\right), 577.1\left(\mathrm{M}^{+}-\mathrm{PPh}_{3}, \mathrm{C}_{2} \mathrm{Ph}\right), 363.0$ $\left(\mathrm{M}^{+}-\mathrm{PPh}_{3}, \mathrm{C}_{2} \mathrm{Ph}, \mathrm{Tp}\right)$. Anal. Calcd for $\mathrm{C}_{53} \mathrm{H}_{44} \mathrm{~N}_{6} \mathrm{BP}_{2} \mathrm{Ru}$ (938.75): C, 67.81; $\mathrm{H}, 4.72 ; \mathrm{N}$, 8.95. Found: C, 68.07; $\mathrm{H}, 4.54$; N, 8.45 .

Synthesis of the Vinylidene complex $\left[\mathrm{Tp}\left(\mathrm{PPh}_{3}\right)_{2^{-}}\right.$ $\mathbf{R} \mathbf{u}=\mathbf{C}=\mathbf{C}(\mathbf{P h}) \mathbf{C H}_{2} \mathbf{C N}$ ]l (2). To a Schlenk flask charged with

(17) Nathaniel, W.; Alock, N. W.; Burns, I. D.; Claire, K. S.; Hill, A. F. Inorg. Chem. 1992, 31, 2906. 
complex 1 (3.10 g, $3.30 \mathrm{mmol}$ ) in $50 \mathrm{~mL}$ of $\mathrm{CH}_{2} \mathrm{Cl}_{2}$ was added $\mathrm{ICH}_{2} \mathrm{CN}(0.46 \mathrm{~mL}, 3.5 \mathrm{mmol})$. The clear solution was stirred for $16 \mathrm{~h}$, and then the solvent was reduced to about $5 \mathrm{~mL}$. This mixture was slowly added to $90 \mathrm{~mL}$ of a vigorously stirred diethyl ether solution. The green precipitate thus formed was filtered off and washed with diethyl ether and hexane to give compound 2 (3.29 g, 90\%). Spectroscopic data for 2: ${ }^{1} \mathrm{H}$ NMR $\left(\mathrm{CDCl}_{3}\right): \delta 7.89(\mathrm{br}, 1 \mathrm{H}, \mathrm{Tp}), 7.62(\mathrm{br}, 2 \mathrm{H}, \mathrm{Tp}), 7.42-6.94(\mathrm{~m}$, $\left.\mathrm{PPh}_{3}, \mathrm{C}_{2} \mathrm{Ph}, \mathrm{Ph}\right), 6.78$ (br, 1H, Tp), 6.66 (br, 1H, Tp), 5.73 (br, $2 \mathrm{H}, \mathrm{Tp}), 5.60$ (br, $1 \mathrm{H}, \mathrm{Tp}), 5.47(\mathrm{br}, 1 \mathrm{H}, \mathrm{Tp}), 3.08\left(\mathrm{~s}, 2 \mathrm{H}, \mathrm{CH}_{2}\right)$. ${ }^{13} \mathrm{C}$ NMR $\left(\mathrm{CDCl}_{3}\right): \delta 375.3\left(\mathrm{t}, \mathrm{J} \mathrm{P}_{-\mathrm{C}}=16.5 \mathrm{~Hz}, \mathrm{C} \alpha\right), 146.2-$ $106.8\left(\mathrm{~m}, \mathrm{Ph}, \mathrm{Tp}, \mathrm{PPh}_{3}, \mathrm{C}_{\beta}\right), 117.4(\mathrm{CN}), 11.4\left(\mathrm{CH}_{2}\right) .{ }^{31} \mathrm{P} \mathrm{NMR}$ $\left(\mathrm{CDCl}_{3}\right): \delta$ 36.5. MS (FAB) m/z: $980.5\left(\mathrm{M}^{+}-\mathrm{I}\right), 718.4\left(\mathrm{M}^{+}-\right.$ I, $\left.\mathrm{PPh}_{3}\right), 577.2\left(\mathrm{M}^{+}-\mathrm{I}, \mathrm{PPh}_{3}, \mathrm{C}_{2} \mathrm{PhCH}_{2} \mathrm{CN}\right)$. Anal. Calcd for $\mathrm{C}_{55} \mathrm{H}_{46} \mathrm{~N}_{7} \mathrm{BIP}{ }_{2} \mathrm{Ru}$ (1105.7): C, 59.74; H, 4.19; N, 8.87. Found: C, 59.67; H, 4.25; N, 8.74.

Synthesis of the Cyclopropenyl Complex $\mathrm{Tp}\left(\mathrm{PPh}_{3}\right)_{2} \mathrm{Ru}$

$\mathbf{C}=\mathbf{C}(\mathbf{P h}) \mathbf{C H C N}$ (3). To a solution of $\mathbf{2}(1.02 \mathrm{~g}, 0.92 \mathrm{mmol})$ in $20 \mathrm{~mL}$ of $\mathrm{CH}_{2} \mathrm{Cl}_{2}$ at $0{ }^{\circ} \mathrm{C}$ was added a solution of $\mathrm{MeONa}$ (10 $\mathrm{mL}, 1 \mathrm{M}$ in $\mathrm{MeOH}$ ). The mixture was stirred for $10 \mathrm{~min}$, and the color changed from green to yellow. The solvent was removed under vacuum at $0{ }^{\circ} \mathrm{C}$, and the solid residue was extracted with cool ether. The extract was filtered through Celite. Solvent of the filtrate was removed under vacuum to give $3\left(0.82 \mathrm{~g}, 91 \%\right.$ yield). Spectroscopic data for 3 : ${ }^{1 H}$ NMR ( $0{ }^{\circ} \mathrm{C}$, acetone): $\delta 7.81(\mathrm{~d}, \mathrm{~J} \mathrm{H}-\mathrm{H}=2.1 \mathrm{~Hz}, 1 \mathrm{H}, \mathrm{Tp}), 7.77(\mathrm{~d}$, $\left.\mathrm{J}_{\mathrm{H}-\mathrm{H}}=2.3 \mathrm{~Hz}, 1 \mathrm{H}, \mathrm{Tp}\right), 7.59(\mathrm{~d}, \mathrm{~J} \mathrm{H}-\mathrm{H}=2.3 \mathrm{~Hz}, 1 \mathrm{H}, \mathrm{Tp}), 7.40-$ $6.94\left(\mathrm{~m}, 33 \mathrm{H}, \mathrm{Ph}, \mathrm{PPh}_{3}\right), 6.89(\mathrm{~d}, \mathrm{~J} H-\mathrm{H}=2.1 \mathrm{~Hz}, 1 \mathrm{H}, \mathrm{Tp}), 6.58-$ $6.54\left(\mathrm{~m}, 2 \mathrm{H}, \mathrm{Ph} \mathrm{PPh}_{3}\right), 5.97\left(\mathrm{~d}, \mathrm{~J}_{\mathrm{H}-\mathrm{H}}=2.3 \mathrm{~Hz}, 1 \mathrm{H}, \mathrm{Tp}\right), 5.83$ $\left(\mathrm{d}, \mathrm{J}_{\mathrm{H}-\mathrm{H}}=2.3 \mathrm{~Hz}, 1 \mathrm{H}, \mathrm{Tp}\right), 5.62\left(\mathrm{t}, \mathrm{J}_{\mathrm{H}-\mathrm{H}}=2.1 \mathrm{~Hz}, 1 \mathrm{H}, \mathrm{Tp}\right)$, $5.44\left(\mathrm{t}, \mathrm{J} \mathrm{J} \mathrm{H-H}_{\mathrm{H}}=2.3 \mathrm{~Hz}, 1 \mathrm{H}, \mathrm{Tp}\right), 5.39\left(\mathrm{t}, \mathrm{J}_{\mathrm{H}-\mathrm{H}}=2.3 \mathrm{~Hz}, 1 \mathrm{H}\right.$, $\mathrm{Tp}), 1.18$ (s, $\left.1 \mathrm{H}, \mathrm{C}_{2} \mathrm{PhCHCN}\right) .{ }^{31} \mathrm{P} N M R\left(0{ }^{\circ} \mathrm{C}\right.$, acetone): $\delta 48.8$, $48.1\left(A B, J_{p-p}=29.9 \mathrm{~Hz}\right)$. MS (FAB) m/z: $980.4\left(M^{+}+1\right)$, $718.3\left(\mathrm{M}^{+}+1-\mathrm{PPh}_{3}\right), 577.2\left(\mathrm{M}^{+}+1-\mathrm{PPh}_{3}, \mathrm{C}_{2} \mathrm{PhCHCN}\right)$.

Synthesis of the Cyclopropenyl Complex $\mathbf{T p}\left(\mathrm{PPh}_{3}\right)$

$\left(\mathbf{C H}_{3} \mathbf{C N}\right) \mathbf{R u C}=\mathbf{C}(\mathbf{P h}) \mathbf{C H C N}$ (4). To a solution of $\mathbf{3}(1.00 \mathrm{~g}$, $1.02 \mathrm{mmol}$ ) in $20 \mathrm{~mL}$ of $\mathrm{CH}_{2} \mathrm{Cl}_{2}$ was added $10 \mathrm{~mL}$ of $\mathrm{CH}_{3} \mathrm{CN}$. The solution was stirred for $30 \mathrm{~min}$, the col or changed from yellow to brown, and then the solution was filtered through Celite. Solvent of the filtrate was removed under vacuum, and the residue was washed with hexane to give $4(0.62 \mathrm{~g}, 80.0 \%$ yield). Two diastereomers of $\mathbf{4}$ in a 4:1 ratio are observed. The minor isomer in solution decomposed after $2 \mathrm{~h}$ at room temperature. Spectroscopic data for 4: ${ }^{1} \mathrm{H}$ NMR (acetone) major compound: $\delta 7.85\left(\mathrm{~d}, \mathrm{~J}_{\mathrm{H}-\mathrm{H}}=2.2 \mathrm{~Hz}, 1 \mathrm{H}, \mathrm{Tp}\right), 7.81(\mathrm{~d}$,

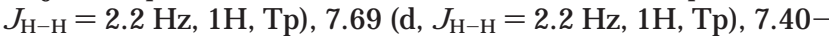
7.07 (m, Ph), 6.86 (1H, Tp), 6.78 (1H, Tp), 6.76 (1H, Tp), 6.02 $\left(t, J_{H-H}=2.2 \mathrm{~Hz}, 1 \mathrm{H}, \mathrm{Tp}\right), 5.98(\mathrm{t}, \mathrm{J} \mathrm{H}-\mathrm{H}=2.2 \mathrm{~Hz}, 1 \mathrm{H}, \mathrm{Tp})$, 5.85 (t, J $\left.\mathrm{H}_{-\mathrm{H}}=2.2 \mathrm{~Hz}, 1 \mathrm{H}, \mathrm{Tp}\right), 2.22\left(\mathrm{~s}, 1 \mathrm{H}, \mathrm{CH}_{3} \mathrm{CN}\right), 1.08(\mathrm{~s}$, $\left.1 \mathrm{H}, \mathrm{C}_{2} \mathrm{PhCHCN}\right)$; minor compound: $\delta 8.10(1 \mathrm{H}, \mathrm{Tp}), 7.40-$ 7.07 (m, Ph, Tp, PPh $)$, $5.74(1 \mathrm{H}, \mathrm{Tp}), 5.61(1 \mathrm{H}, \mathrm{Tp}), 5.96(1 \mathrm{H}$, $\mathrm{Tp}), 2.29$ (s, $1 \mathrm{H}, \mathrm{CH}_{3} \mathrm{CN}$ ), $1.20\left(\mathrm{~s}, 1 \mathrm{H}, \mathrm{C}_{2} \mathrm{PhCHCN}\right) .{ }^{13} \mathrm{C} \mathrm{NMR}$ $\left(\mathrm{CDCl}_{3}\right)$ major compound: $\delta 137.9\left(\mathrm{~d}, \mathrm{~J}_{\mathrm{p}-\mathrm{C}}=11.4 \mathrm{~Hz}, \mathrm{C} \alpha\right)$, 146.9-105.6 (m, Ph, $\left.\mathrm{PPh}_{3}, \mathrm{Tp}\right), 123.7\left(\mathrm{CH}_{3} \mathrm{CN}\right), 114.4(\mathrm{CN})$, 3.6 $\left(\mathrm{CH}_{3} \mathrm{CN}\right), 2.9(\mathrm{CH})$. ${ }^{31} \mathrm{P}$ NMR (acetone): $\delta$ 56.7, $56.0(4: 1)$. MS (FAB) m/z: $759.3\left(\mathrm{M}^{+}+1\right), 718.3\left(\mathrm{M}^{+}+1-\mathrm{CH}_{3} \mathrm{CN}\right), 577.1$ $\left(\mathrm{M}^{+}+1-\mathrm{CH}_{3} \mathrm{CN}, \mathrm{C}_{2} \mathrm{PhCHCN}\right)$. Anal. Calcd for $\mathrm{C}_{39} \mathrm{H}_{33} \mathrm{~N}_{8^{-}}$ BPRu (756.56): C, 61.91; H, 4.40; N, 14.81. Found: C, 62.01; $\mathrm{H}, 4.46 ; \mathrm{N}, 14.50$.

Preparation of [Tp(PPh $\left.)_{2} \mathbf{R u}=\mathbf{C}=\mathbf{C}(\mathbf{P h}) \mathbf{C H}\left(\mathrm{CPh}_{3}\right) \mathrm{CN}\right]-$ $\mathbf{P F}_{6}$ (5). To a solid mixture of $\mathbf{3}(0.25 \mathrm{~g}, 0.26 \mathrm{mmol})$ and $\mathrm{Ph}_{3-}$ $\mathrm{CPF}_{6}\left(0.12 \mathrm{~g}, 0.3 \mathrm{mmol}\right.$, in drybox) at $0{ }^{\circ} \mathrm{C}$, was added $30 \mathrm{~mL}$ of $\mathrm{CH}_{2} \mathrm{Cl}_{2}$. The mixture was stirred for $20 \mathrm{~min}$, and the color changed from yellow to green. Then the solvent was removed under vacuum. The residual solid was washed with $2 \times 20$ $\mathrm{mL}$ of benzene and was dried under vacuum to give complex 5 (0.25 g, 69\% yield). Spectroscopic data for 5: ${ }^{1} \mathrm{H}$ NMR (acetone): $\delta 7.92\left(\mathrm{~d}, \mathrm{~J}_{\mathrm{H}-\mathrm{H}}=2.3 \mathrm{~Hz}, 1 \mathrm{H}, \mathrm{Tp}\right), 7.83\left(\mathrm{~d}, \mathrm{~J}_{\mathrm{H}-\mathrm{H}}=\right.$ $2.3 \mathrm{~Hz}, 1 \mathrm{H}, \mathrm{Tp}), 7.71$ (d, J $\left.\mathrm{H}_{-H}=2.3 \mathrm{~Hz}, 1 \mathrm{H}, \mathrm{Tp}\right), 7.4-6.9(\mathrm{~m}$, $\mathrm{Tp}, \mathrm{Ph}), 6.83(\mathrm{~d}, \mathrm{~J} \mathrm{H}-\mathrm{H}=2.3 \mathrm{~Hz}, 1 \mathrm{H}, \mathrm{Tp}), 5.81(\mathrm{~d}, \mathrm{~J} H-\mathrm{H}=2.2$
$\mathrm{Hz}, 1 \mathrm{H}, \mathrm{Tp}), 5.66\left(\mathrm{~d}, \mathrm{~J}_{\mathrm{H}-\mathrm{H}}=2.2 \mathrm{~Hz}, 1 \mathrm{H}, \mathrm{Tp}\right), 5.63\left(\mathrm{t}, \mathrm{J}_{\mathrm{H}-\mathrm{H}}=\right.$ $2.2 \mathrm{~Hz}, 1 \mathrm{H}, \mathrm{Tp}), 5.54(\mathrm{t}, \mathrm{J} \mathrm{H}-\mathrm{H}=2.2 \mathrm{~Hz}, 1 \mathrm{H}, \mathrm{Tp}), 4.91(\mathrm{~s}, 1 \mathrm{H}$, $\mathrm{CH}) .{ }^{13} \mathrm{C}$ NMR (acetone): $\delta 371.3(\mathrm{t}, \mathrm{J} \mathrm{p}-\mathrm{C}=16.2 \mathrm{~Hz}, \mathrm{C} \alpha$ ), 146.1-106.3 (m, Ph, Tp, $\mathrm{CPh}_{3}, \mathrm{PPh}_{3}, \mathrm{C}_{\beta}$ ), $122.3(\mathrm{CN}), 21.2(\mathrm{CH})$. ${ }^{31} \mathrm{P}$ NMR (acetone): $\delta$ 35.1, $33.6(\mathrm{AB}, \mathrm{J} \mathrm{p}-\mathrm{p}=26.7 \mathrm{~Hz})$. MS $(F A B) \mathrm{m} / \mathrm{z}: 1222.1\left(\mathrm{M}^{+}-\mathrm{PF}_{6}\right), 978.8\left(\mathrm{M}^{+}-\mathrm{PF}_{6}, \mathrm{CPh}_{3}\right), 838.8$ $\left(\mathrm{M}^{+}-\mathrm{PF}_{6}, \mathrm{CPh}_{3}, \mathrm{C}_{2} \mathrm{PhCHCN}\right), 577.2\left(\mathrm{M}^{+}-\mathrm{PF}_{6}, \mathrm{CPh}_{3}\right.$ $\mathrm{C}_{2} \mathrm{PhCHCN}$, $\left.\mathrm{PPh}_{3}\right)$. Anal. Calcd for $\mathrm{C}_{74} \mathrm{H}_{60} \mathrm{~N}_{7} \mathrm{BP}_{3} \mathrm{~F}_{6} \mathrm{Ru}$ (1366.06): C, 65.06; H, 4.43; N, 7.18. Found: C, 65.34; H, 4.41; N, 7.29.

Synthesis of $\left[\mathrm{T} p\left(\mathrm{PPh}_{\mathbf{3}}\right)_{2} \mathbf{R} \mathrm{u}=\mathrm{C}=\mathbf{C}(\mathrm{Ph}) \mathrm{CH}(\mathrm{HgCl}) \mathrm{CN}\right] \mathrm{Cl}$ (6). To a solid mixture of $3(0.51 \mathrm{~g}, 0.52 \mathrm{mmol})$ and $\mathrm{HgCl}_{2}(0.15$ $\mathrm{g}, 0.52 \mathrm{mmol}$ ) at $0{ }^{\circ} \mathrm{C}$ was added $30 \mathrm{~mL}$ of $\mathrm{CH}_{2} \mathrm{Cl}_{2}$. The mixture was stirred for $30 \mathrm{~min}$, and the color changed from yellow to green. Then the solvent was removed under vacuum. The residual solid was extracted with $2 \times 20 \mathrm{~mL}$ of ether, and the solvent was removed under vacuum to give complex $\mathbf{6}(0.45 \mathrm{~g}$, 69\% yield). Spectroscopic data for 6: ${ }^{1} \mathrm{H}$ NMR (acetone): $\delta 8.01$ $\left(\mathrm{d}, \mathrm{J}_{\mathrm{H}-\mathrm{H}}=2.2 \mathrm{~Hz}, 1 \mathrm{H}, \mathrm{Tp}\right), 7.86(\mathrm{~d}, \mathrm{~J} \mathrm{H}-\mathrm{H}=2.3 \mathrm{~Hz}, 1 \mathrm{H}, \mathrm{Tp})$, $7.75\left(\mathrm{~d}, \mathrm{~J}_{\mathrm{H}-\mathrm{H}}=2.3 \mathrm{~Hz} \mathrm{H}, \mathrm{Tp}\right), 7.49-7.07(\mathrm{~m}, \mathrm{Tp}, \mathrm{Ph}), 6.85$ $\left(\mathrm{d}, \mathrm{J}_{\mathrm{H}-\mathrm{H}}=2.2 \mathrm{~Hz} 1 \mathrm{H}, \mathrm{Tp}\right), 5.85\left(\mathrm{~d}, \mathrm{~J}_{\mathrm{H}-\mathrm{H}}=2.2 \mathrm{~Hz}, 1 \mathrm{H}, \mathrm{Tp}\right)$, $5.70(\mathrm{~d}, \mathrm{~J} H-\mathrm{H}=2.2 \mathrm{~Hz}, 1 \mathrm{H}, \mathrm{Tp}), 5.68(\mathrm{t}, \mathrm{J} \mathrm{H}-\mathrm{H}=2.2 \mathrm{~Hz}, 1 \mathrm{H}$, $\mathrm{Tp}), 5.56\left(\mathrm{t}, \mathrm{J}_{\mathrm{H}-\mathrm{H}}=2.2 \mathrm{~Hz}, 1 \mathrm{H}, \mathrm{Tp}\right), 3.19\left(\mathrm{~s}, 1 \mathrm{H}, \mathrm{C}_{2^{-}}\right.$ $\mathrm{PhCHCNHg}) .{ }^{13} \mathrm{C} \mathrm{NMR}\left(\mathrm{CDCl}_{3}\right): \delta 375.1$ (t, J $\mathrm{p}-\mathrm{C}=15.4 \mathrm{~Hz}$, $\mathrm{C} \alpha$ ), 146.8-107.5 (m, Ph, Tp, $\left.\mathrm{PPh}_{3}, \mathrm{C}_{\beta}\right), 120.3(\mathrm{CN}), 23.1(\mathrm{CH})$. 31P NMR (acetone): $\delta$ 35.5, 34.1 (AB, J p-p $=26.9 \mathrm{~Hz})$. MS $(\mathrm{FAB}) \mathrm{m} / \mathrm{z}: 1214.3\left(\mathrm{M}^{+}+1-\mathrm{Cl}\right), 978.8\left(\mathrm{M}^{+}-\mathrm{Cl}, \mathrm{HgCl}\right), 838.8$ $\left(\mathrm{M}^{+}-\mathrm{Cl}, \mathrm{HgCl}, \mathrm{C}_{2} \mathrm{PhCHCN}\right), 577\left(\mathrm{M}^{+}-\mathrm{Cl}, \mathrm{HgCl}, \mathrm{C}_{2^{-}}\right.$ $\mathrm{PhCHCN}, \mathrm{PPh}_{3}$ ). Anal. Calcd for $\mathrm{C}_{55} \mathrm{H}_{45} \mathrm{~N}_{7} \mathrm{BCl}_{2} \mathrm{HgP}_{2} \mathrm{Ru}$ (1249.28): C, 52.87; H, 3.63; N, 7.85. Found: C, 52.42; H, 4.04; N, 8.07.

Synthesis of $\left[\mathrm{Tp}\left(\mathrm{PPh}_{3}\right)\left(\mathrm{CH}_{3} \mathrm{CN}\right) \mathrm{Ru}=\mathrm{C}=\mathrm{C}(\mathrm{Ph}) \mathrm{CH}(\mathrm{HgCl})-\right.$ CN]CI (7). To a solid mixture of $4(0.17 \mathrm{~g}, 0.17 \mathrm{mmol})$ and $\mathrm{HgCl}_{2}(0.046 \mathrm{~g}, 0.17 \mathrm{mmol})$ was added $30 \mathrm{~mL}$ of $\mathrm{CH}_{2} \mathrm{Cl}_{2}$. The mixture was stirred for $10 \mathrm{~min}$, and then the solvent was removed under vacuum. The residual solid was extracted with $2 \times 20 \mathrm{~mL}$ of ether, and after filtration, the solvent was removed under vacuum to give $7(0.12 \mathrm{~g}, 73 \%$ yield). Spectroscopic data for 7: ${ }^{1} \mathrm{H}$ NMR (acetone): $\delta 7.78\left(\mathrm{~d}, \mathrm{~J}_{\mathrm{H}-\mathrm{H}}=2.2\right.$ $\mathrm{Hz}, 1 \mathrm{H}, \mathrm{Tp}), 7.76\left(\mathrm{~d}, \mathrm{~J}_{\mathrm{H}-\mathrm{H}}=2.3 \mathrm{~Hz}, 1 \mathrm{H}, \mathrm{Tp}\right), 7.75\left(\mathrm{~d}, \mathrm{~J}_{\mathrm{H}-\mathrm{H}}=\right.$ $2.3 \mathrm{~Hz}, 1 \mathrm{H}, \mathrm{Tp}), 7.43-7.03(\mathrm{~m}, \mathrm{Tp}, \mathrm{Ph}), 6.40\left(\mathrm{~d}, \mathrm{~J}_{\mathrm{H}-\mathrm{H}}=2.2\right.$ $\mathrm{Hz}, 1 \mathrm{H}, \mathrm{Tp}), 6.33$ (br, $1 \mathrm{H}, \mathrm{Tp}), 6.10$ (t, J $\left.\mathrm{H}_{-\mathrm{H}}=2.2 \mathrm{~Hz}, 1 \mathrm{H}, \mathrm{Tp}\right)$, $5.93(\mathrm{t}, \mathrm{J} \mathrm{H}-\mathrm{H}=2.2 \mathrm{~Hz}, 1 \mathrm{H}, \mathrm{Tp}), 3.69\left(\mathrm{~s}, 1 \mathrm{H}, \mathrm{C}_{2} \mathrm{PhCHCNHg}\right)$, $2.45\left(\mathrm{~s}, 3 \mathrm{H}, \mathrm{CH}_{3} \mathrm{CN}\right.$ ). ${ }^{13} \mathrm{C}$ NMR (acetone): $\delta 369.3$ (d, J $\mathrm{p}-\mathrm{C}=$ $16.1 \mathrm{~Hz}, \mathrm{C} \alpha), 146.8-107.5\left(\mathrm{~m}, \mathrm{Ph}, \mathrm{Tp}, \mathrm{PPh}_{3}, \mathrm{C}_{\beta}\right), 135.0\left(\mathrm{CH}_{3^{-}}\right.$ $\mathrm{CN}), 124.6(\mathrm{CN}), 25.1(\mathrm{CH}), 4.6\left(\mathrm{CH}_{3} \mathrm{CN}\right) .{ }^{31} \mathrm{P}$ NMR (acetone): $\delta$ 45.9. MS (FAB) m/z: $994.8\left(\mathrm{M}^{+}-\mathrm{Cl}\right), 758.8\left(\mathrm{M}^{+}-\mathrm{Cl}, \mathrm{HgCl}\right)$, $618.4\left(\mathrm{M}^{+}-\mathrm{Cl}, \mathrm{HgCl}, \mathrm{C}_{2} \mathrm{PhCHCN}\right), 577.2\left(\mathrm{M}^{+}-\mathrm{Cl}, \mathrm{HgCl}\right.$, $\left.\mathrm{C}_{2} \mathrm{PhCHCN}, \mathrm{CH}_{3} \mathrm{CN}\right)$.

Reaction of $\mathbf{6}$ with MeONa. To a solution of $\mathbf{6}(0.43 \mathrm{~g}$, $0.34 \mathrm{mmol}$ ) in $20 \mathrm{~mL}$ of $\mathrm{CH}_{2} \mathrm{Cl}_{2}$ at $0{ }^{\circ} \mathrm{C}$ was added a solution of $\mathrm{MeONa}(1 \mathrm{~mL}, 1 \mathrm{M}$ in $\mathrm{MeOH}$ ). The mixture was stirred for $10 \mathrm{~min}$, and then the solvent was removed at $0{ }^{\circ} \mathrm{C}$ under vacuum, the solid residue was extracted with cool ether, and the extract was filtered through Celite. Solvent of the filtrate was removed under vacuum to give $3(0.245 \mathrm{~g}, 71 \%$ yield).

Reaction of 7 with MeONa. To a solution of $7(0.37 \mathrm{~g}$, $0.35 \mathrm{mmol}$ ) in $20 \mathrm{~mL}$ of $\mathrm{CH}_{2} \mathrm{Cl}_{2}$ at $0{ }^{\circ} \mathrm{C}$ was added a solution of $\mathrm{MeONa}(1 \mathrm{~mL}, 1 \mathrm{M}$ in $\mathrm{MeOH}$ ). The mixture was stirred for $25 \mathrm{~min}$, and the color changed from green to yellow. The solvent was removed at $0{ }^{\circ} \mathrm{C}$ under vacuum, the solid residue was extracted with cool ether, and the extract was filtered through Celite. Solvent of the resulting solution was removed under vacuum to give $\mathbf{4}(0.17 \mathrm{~g}, 63 \%$ yield).

Preparation of $\mathrm{Tp}\left(\mathrm{PPh}_{3}\right) \mathrm{Ru}\left(\mathrm{C}_{3} \mathrm{H}_{3} \mathrm{NN}\right) \mathrm{C}=\mathrm{C}(\mathrm{Ph}) \mathrm{CH}_{2} \mathrm{CN}$ (8a). To a solid mixture of $\mathbf{3}(1.02 \mathrm{~g}, 1.02 \mathrm{mmol})$ and pyrazole $\left(0.07 \mathrm{~g}, 1.02 \mathrm{mmol}\right.$ ) was added $30 \mathrm{~mL}$ of $\mathrm{CH}_{2} \mathrm{Cl}_{2}$. The mixture was stirred for $60 \mathrm{~min}$, and the color changed from yellow to bright yellow. Then the solvent was removed under vacuum. The residual solid was extracted with $2 \times 20 \mathrm{~mL}$ of ether, and the solvent was filtered through Celite. Solvent of the resulting 
solution was removed under vacuum to give $\mathbf{8 a}(0.61 \mathrm{~g}, 79 \%$ yield). Spectroscopic data for 8a: ${ }^{1} \mathrm{H}$ NMR (acetone): $\delta 7.84$ $\left(d, J_{H-H}=2.1 \mathrm{~Hz}, 1 \mathrm{H}, \mathrm{Tp}\right), 7.83\left(\mathrm{~d}, \mathrm{~J}_{\mathrm{H}-\mathrm{H}}=2.2 \mathrm{~Hz}, 1 \mathrm{H}, \mathrm{Tp}\right)$, $7.82\left(\mathrm{~d}, \mathrm{~J}_{\mathrm{H}-\mathrm{H}}=2.1 \mathrm{~Hz}, 1 \mathrm{H}, \mathrm{TP}\right), 7.43-7.10$ (m, Ph, Tp), 7.15 $\left(\mathrm{d}, \mathrm{J}_{\mathrm{H}-\mathrm{H}}=2.2 \mathrm{~Hz}, 1 \mathrm{H}, \mathrm{Tp}\right), 7.08\left(\mathrm{~d}, \mathrm{~J} \mathrm{H}-\mathrm{H}^{2}=2.2 \mathrm{~Hz}, 1 \mathrm{H}, \mathrm{Tp}\right)$, $7.02\left(\mathrm{~d}, \mathrm{~J}_{\mathrm{H}-\mathrm{H}}=2.1 \mathrm{~Hz}, 1 \mathrm{H}, \mathrm{Tp}\right), 6.68\left(\mathrm{~d}, \mathrm{~J}_{\mathrm{H}-\mathrm{H}}=2.1 \mathrm{~Hz}, 1 \mathrm{H}\right.$, $T p), 6.17\left(t, J{ }_{H-H}=2.2 \mathrm{~Hz}, 1 \mathrm{H}, T p\right), 5.97(\mathrm{t}, \mathrm{J} \mathrm{H}-\mathrm{H}=2.1 \mathrm{~Hz}$, $1 \mathrm{H}, \mathrm{Tp}), 5.94\left(\mathrm{~d}, \mathrm{~J}_{\mathrm{H}-\mathrm{H}}=2.2 \mathrm{~Hz}, 1 \mathrm{H}, \mathrm{Tp}\right), 5.85\left(\mathrm{t}, \mathrm{J}_{\mathrm{H}-\mathrm{H}}=2.2\right.$ $\mathrm{Hz}, 1 \mathrm{H}, \mathrm{Tp}), 5.61\left(\mathrm{t}, \mathrm{J}_{\mathrm{H}-\mathrm{H}}=2.1 \mathrm{~Hz}, 1 \mathrm{H}, \mathrm{Tp}\right), 3.35\left(\mathrm{~d}, \mathrm{~J}_{\mathrm{H}-\mathrm{H}}=\right.$ $17.3 \mathrm{~Hz}, 1 \mathrm{H}, \mathrm{C}_{2} \mathrm{PhCHHCN}$ ), 3.18 (d, J $\mathrm{H}_{-\mathrm{H}}=17.3 \mathrm{~Hz}, 1 \mathrm{H}, \mathrm{C}_{2^{-}}$ PhCHHCN ). ${ }^{13} \mathrm{C}$ NMR (acetone): $\delta 163.3(\mathrm{~d}, \mathrm{~J} \mathrm{P}-\mathrm{C}=12.3 \mathrm{~Hz})$, 147.4-127.1 (Ph, $\left.\mathrm{PPh}_{3}, \mathrm{Tp}\right), 119.6(\mathrm{CN}), 14.1\left(\mathrm{C}_{2} \mathrm{PhCH}_{2} \mathrm{CN}\right)$. 31P NMR (acetone): $\delta$ 61.3. MS (FAB) m/z: $758.2\left(\mathrm{M}^{+}+1\right)$, $718.1\left(\mathrm{M}^{+}-\mathrm{P}_{\mathrm{Z}}\right), 577.1\left(\mathrm{M}^{+}-\mathrm{P}_{\mathrm{Z}}, \mathrm{C}_{2} \mathrm{PhCHCN}\right)$. Anal. Calcd for $\mathrm{C}_{40} \mathrm{H}_{34} \mathrm{~N}_{9} \mathrm{BPRu}$ (938.75): C, 61.31; $\mathrm{H}, 4.37 ; \mathrm{N}, 16.09$. Found: $\mathrm{C}, 61.47 ; \mathrm{H}, 4.44 ; \mathrm{N}, 16.30$. An intermediate was observed if the reaction was monitored by NMR spectroscopy within $20 \mathrm{~min}$. Spectroscopic data for $\mathbf{A}:{ }^{1} \mathrm{H}$ NMR (acetone): $\delta 8.03$ (br, 1H, Tp), 7.96 (br, 1H, Tp), 7.83 (br, 1H, Tp), 7.437.10 (m, Ph, Tp), 7.65 (br, 1H, Tp), 6.53 (br, 1H, Tp), 6.24 (br, $1 \mathrm{H}, \mathrm{Tp}), 6.03$ (br, 1H, Tp), 5.83 (br, 1H, Tp), 5.40 (br, 1H, Tp), 4.40, 4.11 (two d, J $\mathrm{H}-\mathrm{H}=18.4 \mathrm{~Hz}, 2 \mathrm{H}, \mathrm{CH}_{2} \mathrm{CN}$ ). ${ }^{31} \mathrm{P} \mathrm{NMR}$ (acetone): $\delta 36.7$.

Preparation of $\mathrm{Tp}\left(\mathrm{PPh}_{3}\right) \mathrm{Ru}\left(\mathrm{Me}_{2} \mathrm{C}_{3} \mathrm{HNN}\right) \mathrm{C}=\mathrm{C}(\mathrm{Ph}) \mathrm{CH}_{2^{-}}$ CN (8b). To a solid mixture of $\mathbf{5 b}(0.40 \mathrm{~g}, 0.41 \mathrm{mmol})$ and 3,5dimethylpyrazole $(0.056 \mathrm{~g}, 0.82 \mathrm{mmol})$ was added $30 \mathrm{~mL}$ of $\mathrm{CH}_{2} \mathrm{Cl}_{2}$. The mixture was stirred for $20 \mathrm{~min}$, and then the solvent was removed under vacuum. The residual solid was extracted with $2 \times 20 \mathrm{~mL}$ of ether, and the solution was filtered through Celite. Solvent of the filtrate was removed under vacuum to give $\mathbf{8 b}$ ( $0.163 \mathrm{~g}, 49 \%$ yield). Spectroscopic data for 8b: ${ }^{1} \mathrm{H}$ NMR (acetone): $\delta 7.81(\mathrm{~d}, \mathrm{~J} \mathrm{H}-\mathrm{H}=2.0 \mathrm{~Hz}, 1 \mathrm{H}$, $T p), 7.51\left(\mathrm{~d}, \mathrm{~J} H-\mathrm{H}_{\mathrm{H}}=2.0 \mathrm{~Hz}, 1 \mathrm{H}, \mathrm{Tp}\right), 7.42(\mathrm{~d}, \mathrm{~J} \mathrm{H}-\mathrm{H}=2.0 \mathrm{~Hz}$, $1 \mathrm{H}, \mathrm{Tp}), 7.43-6.84(\mathrm{~m}, \mathrm{Ph}, \mathrm{Tp}), 6.60(\mathrm{~d}, \mathrm{~J} \mathrm{H}-\mathrm{H}=2.1 \mathrm{~Hz}, 1 \mathrm{H}$, $\mathrm{Tp}), 6.13(\mathrm{t}, \mathrm{J} \mathrm{H}-\mathrm{H}=2.0 \mathrm{~Hz}, 1 \mathrm{H}, \mathrm{Tp}), 5.97(\mathrm{t}, \mathrm{J} \mathrm{H}-\mathrm{H}=2.1 \mathrm{~Hz}$, $1 \mathrm{H}, \mathrm{Tp}), 5.94\left(\mathrm{~d}, \mathrm{~J}_{\mathrm{H}-\mathrm{H}}=2.1 \mathrm{~Hz}, 1 \mathrm{H}, \mathrm{Tp}\right), 5.61\left(\mathrm{t}, \mathrm{J}_{\mathrm{H}-\mathrm{H}}=2.0\right.$ $\mathrm{Hz}, 1 \mathrm{H}, \mathrm{Tp}$ ), 3.25, 3.17 (two d, J $\mathrm{H}-\mathrm{H}=17.1 \mathrm{~Hz}, 2 \mathrm{H}, \mathrm{CH}_{2} \mathrm{CN}$ ), 2.38, $2.13\left(\mathrm{~s}, 3 \mathrm{H},\left(\mathrm{CH}_{3}\right)_{2} \mathrm{C}_{3} \mathrm{HNN}\right) .{ }^{13} \mathrm{C}$ NMR (acetone): $\delta 162.2$ $(d, J P-C=12.6 \mathrm{~Hz}), 146.1-127.1\left(\mathrm{PPh}_{3}, \mathrm{Tp}, \mathrm{Ph}\right), 118.7(\mathrm{CN})$, $15.3\left(\mathrm{C}_{2} \mathrm{PhCH}_{2} \mathrm{CN}\right)$, 16.8, $15.3\left(\left(\mathrm{CH}_{3}\right)_{2} \mathrm{C}_{3} \mathrm{HNN}\right)$. 31P NMR (acetone): $\delta$ 61.0. MS (FAB) m/z: $814.2\left(\mathrm{M}^{+}\right), 718.1\left(\mathrm{M}^{+}-\right.$ $\mathrm{Me}_{2} \mathrm{C}_{3} \mathrm{HNN}$ ), $577.1\left(\mathrm{M}^{+}-\mathrm{Me}_{2} \mathrm{C}_{3} \mathrm{HNN}, \mathrm{C}_{2} \mathrm{PhCHCN}\right)$.

Synthesis of $\mathrm{Tp}\left(\mathrm{PPh}_{3}\right)(\mathrm{CO}) \mathrm{RuC}(\mathrm{OMe})=\mathrm{C}(\mathrm{Ph}) \mathrm{CH}_{2} \mathrm{CN}$ (9). A solution of $\mathbf{3}(1.5 \mathrm{~g}, 1.53 \mathrm{mmol})$ was dissolved in methanol under $\mathrm{CO}$ atmosphere. After stirring for $50 \mathrm{~min}$, the yellow solution became brown. The solution was filtered through Celite, and the solvent of the resulting solution was removed under vacuum to give the product 9 (1.01 g, 85\% yield). Spectroscopic data for 9: IR (acetone): $v_{\mathrm{CO}} 1957 \mathrm{~cm}^{-1}$ (s). ${ }^{1} \mathrm{H}$ NMR (acetone): $\delta 8.00\left(\mathrm{~d}, \mathrm{~J}_{\mathrm{H}-\mathrm{H}}=1.9 \mathrm{~Hz}, 1 \mathrm{H}, \mathrm{Tp}\right), 7.82$ (m, 2H, Tp), $7.78\left(\mathrm{~d}, \mathrm{~J}_{\mathrm{H}-\mathrm{H}}=2.2 \mathrm{~Hz}, 1 \mathrm{H}, \mathrm{Tp}\right), 7.52-7.03(\mathrm{~m}$, $\mathrm{Ph}, \mathrm{Tp}), 6.34\left(\mathrm{~d}, \mathrm{~J} \mathrm{JH}_{\mathrm{H}}=1.9 \mathrm{~Hz}, 1 \mathrm{H}, \mathrm{Tp}\right), 6.27\left(\mathrm{t}, \mathrm{J}_{\mathrm{H}-\mathrm{H}}=2.2\right.$ $\mathrm{Hz}, 1 \mathrm{H}, \mathrm{Tp}), 5.92\left(\mathrm{t}, \mathrm{J} \mathrm{H}_{-\mathrm{H}}=2.2 \mathrm{~Hz}, 1 \mathrm{H}, \mathrm{Tp}\right), 5.82\left(\mathrm{~d}, \mathrm{~J}_{\mathrm{H}-\mathrm{H}}=\right.$ $1.9 \mathrm{~Hz}, 1 \mathrm{H}, \mathrm{Tp}), 3.84$ (d, J $\mathrm{H}_{-\mathrm{H}}=16.8 \mathrm{~Hz}, 1 \mathrm{H}, \mathrm{C}_{2} \mathrm{PhCHHCN}$ ), $3.02\left(\mathrm{~d}, \mathrm{~J} \mathrm{H}-\mathrm{H}^{2}=16.8 \mathrm{~Hz}, 1 \mathrm{H}, \mathrm{C}_{2} \mathrm{PhCHHCN}\right), 2.85$ (s, 3H, OMe). ${ }^{13} \mathrm{C}$ NMR (acetone): $\delta 204.2$ (d, J p-c $\left.=15.1 \mathrm{~Hz}, \mathrm{CO}\right), 188.3$ (d, $\mathrm{J}_{\mathrm{P}-\mathrm{C}}=14.0 \mathrm{~Hz}, \mathrm{C} \alpha$ ), 146.5-124.5 (Ph), 119.9 (CN), 56.1 (OMe), $22.4\left(\mathrm{C}_{2} \mathrm{PhCH}{ }_{2} \mathrm{CN}\right)$. ${ }^{31} \mathrm{P} \mathrm{NMR}$ (acetone): $\delta$ 46.9. MS (FAB) $\mathrm{m} / \mathrm{z}: 777.3\left(\mathrm{M}^{+}\right), 605.2\left(\mathrm{M}^{+}-(\mathrm{OMe}) \mathrm{C}=\mathrm{C}(\mathrm{Ph})\left(\mathrm{CH}_{2} \mathrm{CN}\right)\right), 577.1$ $\left(\mathrm{M}^{+}-(\mathrm{OMe}) \mathrm{C}=\mathrm{C}(\mathrm{Ph})\left(\mathrm{CH}_{2} \mathrm{CN}\right),-\mathrm{CO}\right)$. Anal. Calcd for $\mathrm{C}_{39} \mathrm{H}_{34^{-}}$ $\mathrm{O}_{2} \mathrm{~N}_{7} \mathrm{BPRu}$ (775.56): C, 60.39; $\mathrm{H}, 4.42 ; \mathrm{N}, 16.09$. Found: $\mathrm{C}$, $60.71 ; \mathrm{H}, 4.51 ; \mathrm{N}, 16.41$.

Synthesis of $\left[\mathrm{Tp}\left(\mathrm{PPh}_{3}\right)(\mathrm{CO}) \mathrm{Ru}=\mathrm{C}(\mathrm{OMe}) \mathrm{CH}(\mathrm{Ph}) \mathrm{CH}_{2} \mathrm{CN}\right]-$ [CF ${ }_{3}$ COO] (10). Complex 9 (0.072 g, $\left.0.093 \mathrm{mmol}\right)$ was dissolved in $0.5 \mathrm{~mL}$ of $\mathrm{CD}_{3} \mathrm{C}(\mathrm{O}) \mathrm{CD}_{3}$ at $0{ }^{\circ} \mathrm{C}$, and $\mathrm{CF}_{3} \mathrm{COOH}(0.03$
$\mathrm{mL}$ ) was added. After $5 \mathrm{~min}$, the solvent was removed under vacuum, and the product was washed with hexane and was identified as 10. Spectroscopic data for 10: IR (acetone): $v_{\mathrm{CO}}$ $1998 \mathrm{~cm}^{-1}$ (s). ${ }^{1} \mathrm{H}$ NMR (acetone): $\delta 8.38$ (br, $\left.1 \mathrm{H}, \mathrm{Tp}\right), 8.10$ (br, 1H, Tp), 7.98-7.05 (m, Ph, Tp), 6.67 (br, 1H, Tp), 6.35 (br, $1 \mathrm{H}, \mathrm{Tp}), 6.30$ (br, $1 \mathrm{H}, \mathrm{Tp}), 6.10(\mathrm{br}, 1 \mathrm{H}, \mathrm{Tp}), 5.51$ (br, $1 \mathrm{H}$, $\mathrm{Tp}$ ), 5.31 (dd, J $\mathrm{H}_{-\mathrm{H}}=5.4 \mathrm{~Hz}, \mathrm{~J} \mathrm{H}-\mathrm{H}=10.1 \mathrm{~Hz}, \mathrm{H}, \mathrm{CCHPhCH}_{2^{-}}$ $\mathrm{CN}), 4.78(\mathrm{~s}, 3 \mathrm{H}, \mathrm{OMe}), 3.31\left(\mathrm{~m}, 2 \mathrm{H}, \mathrm{C}_{2} \mathrm{PhCH}_{2} \mathrm{CN}\right) .{ }^{13} \mathrm{C} N M R$ (acetone): $\delta 319.9(\mathrm{~d}, \mathrm{~J} \mathrm{p}-\mathrm{c}=10.0 \mathrm{~Hz}, \mathrm{C} \alpha), 201.5(\mathrm{~d}, \mathrm{~J} \mathrm{p}-\mathrm{C}=$ $12.8 \mathrm{~Hz}, \mathrm{CO}$ ), 162.2 (q, J F-C $=43.1 \mathrm{~Hz}, \mathrm{CF}_{3} \mathrm{COO}$ ), 146.5-123.5 (Ph), $118.7\left(\mathrm{q}, \mathrm{J}-\mathrm{C}=282.0 \mathrm{~Hz}, \mathrm{CF}_{3} \mathrm{COO}\right), 117.5$ (CN), 70.4 (OMe), $64.2\left(\mathrm{CCPhCH}_{2} \mathrm{CN}\right), 29.0\left(\mathrm{C}_{2} \mathrm{PhCH}_{2} \mathrm{CN}\right) .{ }^{31} \mathrm{P} \mathrm{NMR}$ (acetone): $\delta$ 36.9. MS (FAB) m/z: $778.3\left(\mathrm{M}^{+}\right), 605.2\left(\mathrm{M}^{+}-\right.$ (OMe)CH(Ph) $\left.\left(\mathrm{CH}_{2} \mathrm{CN}\right)\right), 577.1\left(\mathrm{M}^{+}-(\mathrm{OMe}) \mathrm{CH}(\mathrm{Ph})\left(\mathrm{CH}_{2} \mathrm{CN}\right)\right.$, $-\mathrm{CO})$.

Synthesis of $\mathrm{Tp}\left(\mathrm{PPh}_{3}\right)(\mathrm{CO}) \mathrm{RuC}(\mathrm{O}) \mathrm{CH}(\mathrm{Ph}) \mathrm{CH}_{2} \mathrm{CN}$ (11). Complex $9(0.072 \mathrm{~g}, 0.093 \mathrm{mmol})$ was dissolved in $0.5 \mathrm{~mL}$ of $\mathrm{CD}_{3} \mathrm{C}(\mathrm{O}) \mathrm{CD}_{3}$ at $0{ }^{\circ} \mathrm{C}$, and $\mathrm{CF}_{3} \mathrm{COOH}(0.03 \mathrm{~mL})$ was added. After $36 \mathrm{~h}$, the solvent was removed under vacuum, and the product was washed with hexane and was identified as $\mathbf{1 1}$. Spectroscopic data for 11: IR (acetone): $v_{\text {Co }} 1983 \mathrm{~cm}^{-1}$ (s). ${ }^{1} \mathrm{H}$ NMR (acetone): $\delta$ 7.98-7.11 (m, Ph, Tp), 6.49 (br, 1H, Tp), 6.24 (br, 1H, Tp), 6.04 (br, 1H, Tp), 5.99 (br, 1H, Tp), 3.75, $3.21\left(\mathrm{~m}, 2 \mathrm{H}, \mathrm{CH}_{2} \mathrm{CN}\right), 3.21\left(\mathrm{~m}, 1 \mathrm{H}, \mathrm{C}_{2} \mathrm{PhCHHCN}\right), 2.41(\mathrm{~m}$, $\left.1 \mathrm{H}, \mathrm{C}_{2} \mathrm{HPhCH}_{2} \mathrm{CN}\right) .{ }^{13} \mathrm{C} \mathrm{NMR}$ (acetone): $\delta 213.6$ (d, J $\mathrm{P}-\mathrm{C}=$ $13.4 \mathrm{~Hz}, \mathrm{C} \alpha), 207.5(\mathrm{~d}, \mathrm{~J}$ p-c $=12.6 \mathrm{~Hz}, \mathrm{CO}), 146.5-123.5(\mathrm{Ph})$, $119.7(\mathrm{CN}), 54.6\left(\mathrm{CCHPhCH}{ }_{2} \mathrm{CN}\right), 24.0\left(\mathrm{C}_{2} \mathrm{PhCH}_{2} \mathrm{CN}\right) .{ }^{31} \mathrm{P}$ NMR (acetone): $\delta$ 41.3. MS (FAB) m/z: $761.2\left(\mathrm{M}^{+}\right), 605.2\left(\mathrm{M}^{+}\right.$ $\left.-\mathrm{C}(\mathrm{O}) \mathrm{CH}(\mathrm{Ph})\left(\mathrm{CH}_{2} \mathrm{CN}\right)\right), 577.1\left(\mathrm{M}^{+}-\mathrm{C}(\mathrm{O}) \mathrm{CH}(\mathrm{Ph})\left(\mathrm{CH}_{2} \mathrm{CN}\right)\right.$, -CO). Anal. Calcd for $\mathrm{C}_{38} \mathrm{H}_{31} \mathrm{O}_{2} \mathrm{~N}_{7} \mathrm{BPRu}$ (760.53): C, 60.01; $\mathrm{H}, 4.11 ; \mathrm{N}, 12.89$. Found: $\mathrm{C}, 59.87 ; \mathrm{H}, 3.95 ; \mathrm{N}, 13.18$.

X-ray Analysis. Dark red crystals of $\mathbf{8 a}$ suitable for $\mathrm{X}$-ray diffraction study were grown directly from $\mathrm{CH}_{2} \mathrm{Cl}_{2}$. A suitable single crystal of dimensions $0.25 \times 0.25 \times 0.20 \mathrm{~mm}^{3}$ was glued to a glass fiber and mounted on an SMART CCD diffractometer. The data were collected using $3 \mathrm{~kW}$ sealed-tube molybdenum $\mathrm{K} \alpha$ radiation ( $\mathrm{T}=295 \mathrm{~K}$ ). Exposure time was $5 \mathrm{~s}$ per frame. Sadabs (Siemens area detector absorption) absorption correction was applied, and decay was negligible. Data were processed and the structure was solved and refined by the SHELXTL program. The structure was solved using direct methods and confirmed by Patterson methods refining on intensities of all data (13 076 reflections) to give $\mathrm{R} 1=0.0426$ and $w R 2=0.0917$ for 13076 unique observed reflections $(I>2 \sigma(I))$. Hydrogen atoms were placed geometrically using the riding model with thermal parameters set to 1.2 times that for the atom to which the hydrogen is attached and 1.5 times that for the methyl hydrogens.

The procedures for the structure determination of $\mathbf{1 1}$ were similar to that of $\mathbf{8 a}$. The final residuals of the refinement R1 (wR2) were 0.042 (0.0956). Final values of all refined atomic positional parameters (with esd's) and tables of thermal parameters are given in the Supporting I nformation.

Acknowledgment. We thank the National Science Council, Taiwan, the Republic of China, for support of this work.

Supporting Information Available: Tables of atomic coordinates, bond lengths and angles, anisotropic thermal parameters, and hydrogen atom positions for $\mathbf{8 a}$ and $\mathbf{1 1}$. This material is available free of charge via the Internet at http://pubs.acs.org.

OM980752Q 